\title{
Binding of $\mathrm{Ca}^{2+}$ to the $\left(\mathrm{Ca}^{2+}-\mathrm{Mg}^{2+}\right)-\mathrm{ATPase}$ of sarcoplasmic reticulum: kinetic studies
}

\author{
Ian M. J. HENDERSON, Anthony P. STARLING, Matthew WICTOME, J. Malcolm EAST and Anthony G. LEE \\ Department of Biochemistry, University of Southampton, Southampton SP9 3TY, Hants., U.K.
}

Stop-flow fluorescence and rapid-filtration methods have been used to establish the kinetics of $\mathrm{Ca}^{2+}$ binding to, and dissociation from, the $\left(\mathrm{Ca}^{2+}-\mathrm{Mg}^{2+}\right)$-ATPase of skeletal-muscle sarcoplasmic reticulum and to define the effects of $\mathrm{H}^{+}$and $\mathrm{Mg}^{2+}$ on $\mathrm{Ca}^{2+}$ binding and dissociation rates. The kinetics have been interpreted in terms of the scheme: $\mathrm{E} 2 \rightleftarrows \mathrm{E} 1 \rightleftarrows \mathrm{E} 1 \mathrm{Ca} \rightleftarrows \mathrm{El}^{\prime} \mathrm{Ca} \rightleftarrows \mathrm{El}^{\prime} \mathrm{Ca}_{2}$. The kinetics of the $\mathrm{E} 2 \rightleftarrows \mathrm{E} 1$ transition have been determined by measuring the rate of change of the fluorescence of the ATPase labelled with 4-nitrobenzo-2-oxa-1,3-diazole after a $\mathrm{pH}$ jump or the addition of $\mathrm{Ca}^{2+}$ to the labelled ATPase in the presence of thapsigargin or thapsivillosin $\mathrm{A}$. It has been shown that $\mathbf{M g}^{2+}$ has a marked effect on $\mathrm{Ca}^{2+}$ dissociation at $\mathrm{pH} 7.2$ and that changes in the tryptophan fluorescence of the ATPase follow the same time course as the dissociation of ${ }^{45} \mathrm{Ca}^{2+}$. It is proposed that the effect of $\mathrm{Mg}^{2+}$ follows from binding to a 'gating' site, as detected by changes in the fluorescence of the ATPase labelled with 4(bromomethyl)-6,7-dimethoxycoumarin. The rate of dissociation of $\mathrm{Ca}^{2+}$ from the ATPase increases with increasing $\mathrm{pH}$. The rate of dissociation of $\mathrm{Ca}^{2+}$ decreases with increasing $\mathrm{Ca}^{2+}$ concentration in the medium, with an apparent affinity for $\mathrm{Ca}^{2+}$ greater than that seen for the change in fluorescence amplitude. It is shown that this follows if the first, inner, $\mathrm{Ca}^{2+}$-binding site on the ATPase has a lower affinity for $\mathrm{Ca}^{2+}$ than the second, outer, site. Effects of $\mathrm{H}^{+}$and $\mathrm{Mg}^{2+}$ on $\mathrm{Ca}^{2+}$ dissociation can be treated by the quasiequilibrium approach. $\mathrm{Mg}^{2+}$ and $\mathrm{H}^{+}$also affect the rate of $\mathrm{Ca}^{2+}$ binding to the ATPase, and effects of $\mathrm{H}^{+}$ and $\mathrm{Mg}^{2+}$ on the $\mathrm{E} 2 \rightleftarrows \mathrm{E} 1$ equilibrium explain the results of experiments in which the concentrations of $\mathrm{H}^{+}$and $\mathrm{Mg}^{2+}$ are jumped.

\section{INTRODUCTION}

In stopped-flow experiments with the $\left(\mathrm{Ca}^{2+}-\mathrm{Mg}^{2+}\right)$-ATPase it has been shown that the fluorescence changes following $\mathrm{Ca}^{2+}$ binding or dissociation are rather slow (Dupont and Leigh, 1978). Initial studies suggested that the changes in tryptophan fluorescence observed on mixing the $\mathrm{Ca}^{2+}$-bound ATPase with EGTA could be described by single exponential decays (Guillain et al., 1980, 1981) but subsequent studies showed that, although this was true at pH 6.0 (Orlowski and Champeil, 1991), decays observed at $\mathrm{pH} 7.2$ in the presence of $\mathbf{M g}^{2+}$ were biphasic (Moutin and Dupont, 1991). Fluorescence changes on binding of $\mathrm{Ca}^{2+}$ to the ATPase at $\mathrm{pH} 7$ were also found to be biphasic (Champeil et al., 1983; Fernandez-Belda et al., 1984). The subsequent development of rapid-filtration methods made it possible to measure the rate of dissociation of $\mathrm{Ca}^{2+}$ directly using radioisotopes (Dupont, 1984). Dissociation of ${ }^{45} \mathrm{Ca}^{2+}$ from the $\mathrm{Ca}^{2+}$-bound ATPase was monoexponential at $\mathrm{pH} 6.0$ on washing with EGTA. However, on washing with ${ }^{40} \mathrm{Ca}^{2+}$, dissociation of the inner $\mathrm{Ca}^{2+}$ occurred at a rate half that of the outer $\mathrm{Ca}^{2+}$ and was inhibited by the presence of ${ }^{40} \mathrm{Ca}^{2+}$ in the medium (Dupont, 1982; Inesi, 1987; Orlowski and Champeil, 1991), consistent with a sequential binding mechanism (Scheme 1). A study of $\mathrm{Ca}^{2+}$ dissociation from the ATPase using an assay based on phosphorylation of the ATPase by ATP was also interpreted in

$$
\mathrm{E}^{\prime} \mathrm{Ca}_{2} \rightarrow \mathrm{E}^{\prime} \mathrm{Ca} \rightarrow \mathrm{E} 1 \mathrm{Ca} \rightarrow \mathrm{E} 1 \rightarrow \mathrm{E} 2
$$

terms of dissociation of the inner $\mathrm{Ca}^{2+}$ at half the rate of the outer $\mathrm{Ca}^{2+}$ at $\mathrm{pH} 7.0$ in the presence of $\mathrm{Mg}^{2+}$ (Petithory and Jencks, 1988). Direct studies of ${ }^{45} \mathrm{Ca}^{2+}$ dissociation from the ATPase, however, suggested a more complex relationship under these conditions (Starling et al., 1993).

Here we have reinvestigated the kinetics of $\mathrm{Ca}^{2+}$ binding and dissociation, largely using stopped-flow fluorescence methods. In combination with the equilibrium measurements reported in the preceding paper (Henderson et al., 1994), they allow the development of a fairly simple model for the $\mathrm{Ca}^{2+}$-binding process.

\section{MATERIALS AND METHODS}

Sarcoplasmic reticulum from rabbit skeletal muscle and $\left(\mathrm{Ca}^{2+}-\right.$ $\mathrm{Mg}^{2+}$ )-ATPase were prepared as described in the preceding paper (Henderson et al., 1994). ATPase was labelled with 4-nitrobenzo2-oxa-1,3-diazole (NBD) also as described (Henderson et al., 1994). Thapsigargin was obtained from Calbiochem and trilobolide was a generous gift from Dr. M. Holub.

Rapid-kinetic fluorescence measurements were performed using a Biologic SFM-3 fluorimeter with BioKine V3.20a software for data acquisition and analysis. The instrument uses stepper motors to drive three mixing syringes arranged to feed into two mixers followed by the observation cuvette. The instrument has no stop syringe, but a high-speed electrovalve at the exit of the cuvette closes with the stopping of the motors to halt any liquid flow. Tryptophan fluorescence was excited through a monochromator set at $290 \mathrm{~nm}$, and emitted light was collected at $90^{\circ}$ and filtered by a high-pass cut-off filter with $50 \%$ transmission at $320 \mathrm{~nm}$ (UV 32, Andover Corporation). Fluorescence of the NBD-labelled ATPase was excited at $430 \mathrm{~nm}$, and emission was filtered through a high-pass cut-off filter with 
$50 \%$ transmission at $455 \mathrm{~nm}$ (GG 455, Andover Corporation). Experiments were performed at $25^{\circ} \mathrm{C}$ unless otherwise stated.

The time-dependence of ${ }^{45} \mathrm{Ca}^{2+}$ release from the ATPase was determined using a Biologic RFS-04 rapid-filtration system, at room temperature (typically $20^{\circ} \mathrm{C}$ ). A suspension of the ATPase $(0.2 \mathrm{mg})$ in buffer containing $100 \mu \mathrm{M}{ }^{45} \mathrm{Ca}^{2+}$ and $500 \mu \mathrm{M}$ $\left[{ }^{3} \mathrm{H}\right]$ sucrose was loaded on to a Millipore HAWP filter $(0.45 \mu \mathrm{m})$ and then rapidly perfused with buffer. The filter was dried overnight in air and counted in OptiPhase HiSafe 3. The amount of $\left[{ }^{3} \mathrm{H}\right]$ sucrose trapped on the filter was used to calculate the wetting volume of the filter, and the amount of ${ }^{45} \mathrm{Ca}^{2+}$ calculated to be in this volume was subtracted from the total ${ }^{45} \mathrm{Ca}^{2+}$ on the filter to give that bound to the ATPase.

Simulations of $\mathrm{Ca}^{2+}$ dissociation were performed on an IBMcompatible PC using the program M30 of Zhang et al. (1989), which uses the method of Laplace transforms to solve differential equations, or on an IBM 3090 using FACSIMILE (Chance et al., 1977). In all simulations it was assumed that $\mathrm{H}^{+}$binding was fast compared with the rates of $\mathrm{Ca}^{2+}$ binding or dissociation so that $\mathrm{H}^{+}$binding can be treated by the quasiequilibrium approach (Cha, 1968). This assumption is justified below. Free concentrations of $\mathrm{Ca}^{2+}$ were calculated using the binding constants for $\mathrm{Ca}^{2+}, \mathrm{Mg}^{2+}$ and $\mathrm{H}^{+}$to EGTA given by Godt (1974).

\section{RESULTS}

\section{Comparison of ${ }^{45} \mathrm{Ca}^{2+}$ dissociation and tryptophan-fluorescence changes}

Figure 1(a) shows an experiment in which the ATPase incubated with ${ }^{45} \mathrm{Ca}^{2+}$ was adsorbed on a cellulose filter and was perfused for various times with a medium containing $2 \mathrm{mM}$ EGTA at $\mathrm{pH}$ 7.2. Plotted on the same Figure is the decrease in tryptophan fluorescence observed when the ATPase incubated in $100 \mu \mathrm{M}$ $\mathrm{Ca}^{2+}$ at $\mathrm{pH} 7.2$ is mixed in a stopped-flow fluorimeter with an equal volume of $2 \mathrm{mM}$ EGTA to give a final $\mathrm{pCa}$ value of 7.5 ; the fluorescence change is plotted on a scale of 1 to zero to allow comparison with the ${ }^{45} \mathrm{Ca}^{2+}$ dissociation data. The ${ }^{45} \mathrm{Ca}^{2+}$ and tryptophan data fit well to single exponentials with rates of 10.3 and $8.5 \mathrm{~s}^{-1}$ respectively, but comparison of the data (Figure 1a) shows that, within the limited accuracy of the ${ }^{45} \mathrm{Ca}^{2+}$ data, both sets of data fit to the same curve. Figure 1(b) shows the same experiment but in the presence of $20 \mathrm{mM} \mathrm{Mg^{2+ }}$. It is clear that the data no longer fit to a single exponential but again the loss of ${ }^{45} \mathrm{Ca}^{2+}$ and the decrease in tryptophan fluorescence follow the same curve within experimental error.

The close agreement between the ${ }^{45} \mathrm{Ca}^{2+}$ and tryptophan data is shown in more dramatic form in Figure 2. As reported by Squier et al. (1990), displacement of ${ }^{45} \mathrm{Ca}^{2+}$ from the ATPase by $\mathrm{Pr}^{3+}$ is biphasic, with one-half of the $\mathrm{Ca}^{2+}$ dissociating with a rate comparable with that seen in perfusion with EGTA, the other half dissociating over a long time course of minutes, not shown in Figure 2. The important observation is that even under these extreme conditions, the change in tryptophan-fluorescence intensity accurately monitors the $\mathrm{Ca}^{2+}$ occupancy of the ATPase. An explanation was presented in the preceding paper (Henderson et al., 1994).

\section{Effects of $\mathrm{pH}$ and $\mathrm{Mg}^{2+}$ on the tryptophan fluorescence changes accompanying $\mathrm{Ca}^{2+}$ dissociation}

As shown in Figures 1 and 3, the rate of decrease in tryptophan fluorescence produced by mixing the ATPase in $100 \mu \mathrm{M} \mathrm{Ca}^{2+}$ with $2 \mathrm{mM}$ EGTA increases with increasing $\mathrm{pH}$. Further, whereas curves obtained at pH 6 and 7.2 in the absence of $\mathrm{Mg}^{2+}$ fit well to single exponentials with rates of $4.0 \pm 0.1$ and $8.5 \pm 0.1 \mathrm{~s}^{-1}$ respectively, that at $\mathrm{pH} 8.5$ fits to the sum of two exponentials of equal amplitude and rates of 6.7 and $64.7 \mathrm{~s}^{-1}$. Addition of $20 \mathrm{mM} \mathrm{Mg}^{2+}$ has no significant effects on rate at pH 6.0 (Figure 3). In contrast, $\mathrm{Mg}^{2+}$ increases the rate of the fluorescence change at $\mathrm{pH} 7.2$, the curves no longer fitting to a single exponential (Figure 1). When the data at low concentrations of $\mathrm{Mg}^{2+}$ are fitted without restraint to the sum of two exponentials, good fits can be obtained with a wide range of combinations of amplitudes and rates. However, at high $\mathrm{Mg}^{2+}(50 \mathrm{mM})$ stable fits were obtained to two exponentials with rates of $46 \mathrm{~s}^{-1}$ and $6 \mathrm{~s}^{-1}$ and relative amplitudes of 0.52 and 0.48 respectively (Figure 4). With the rate of the fast component fixed at $46 \mathrm{~s}^{-1}$, good fits could then be obtained to the data at lower $\mathrm{Mg}^{2+}$ concentrations, with a rate for the slow component between 5 and $7 \mathrm{~s}^{-1}$ and relative amplitudes for the two components shown in Figure 4.

The effects of $\mathrm{Mg}^{2+}$ on the rate of the fluorescence decrease at pH 8.5 are more complex (Figure 3), with low concentrations increasing the rate of the fluorescence change and high concentrations decreasing the rate. Whereas rates recorded at $0,0.5$ and $1 \mathrm{mM} \mathrm{Mg}^{2+}$ were biexponential, at $2 \mathrm{mM}$ and above they became

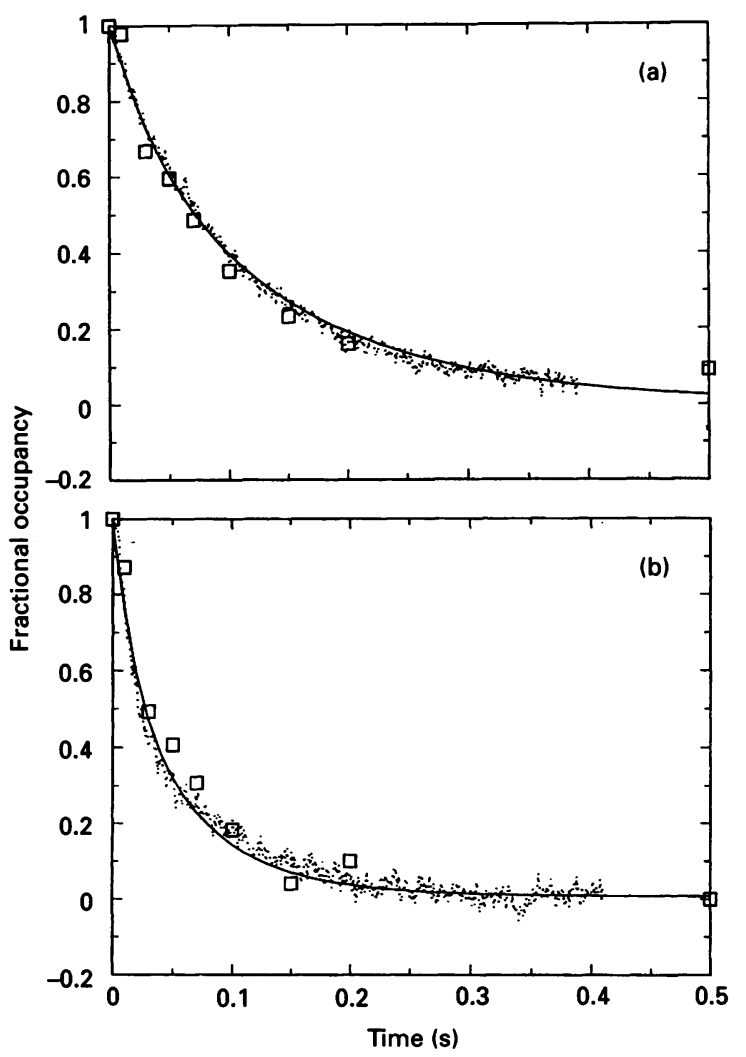

Figure 1 Comparison of ${ }^{45} \mathrm{Ca}^{2+}$ dissociation from the $\left(\mathrm{Ca}^{2+}-\mathrm{Mg}^{2+}\right)$-ATPase with the change in tryptophan-fluorescence intensity

The symbols $(\square)$ show the dissociation of ${ }^{45} \mathrm{Ca}^{2+}$ when the ATPase incubated in buffer $(20 \mathrm{mM}$ Mops/Tris, $\mathrm{pH}$ 7.2) containing $50 \mu \mathrm{M}{ }^{45} \mathrm{Ca}^{2+}$ was perfused with the same buffer containing $2 \mathrm{mM}$ EGTA in the absence of $\mathrm{Mg}^{2+}$ (a) or in the presence of $20 \mathrm{mM} \mathrm{Mg}^{2+}$ (b). The dotted line shows the decrease in tryptophan-fluorescence intensity plotted on a scale from 1 to zero when the ATPase in buffer (150 mM Mops, $80 \mathrm{mM}$ Tris, pH 7.2, $100 \mu \mathrm{M} \mathrm{Ca}^{2+}$ ) was mixed in a 1:1 ratio with the same buffer containing $2 \mathrm{mM} \mathrm{EGTA}$, in the absence of $\mathrm{Mg}^{2+}$ (a) or in the presence of $20 \mathrm{mM} \mathrm{Mg}^{2+}$ (b). The solid lines show simulations calculated by using the parameters given in Table 1 . 


\section{Table 1 The reaction steps, rate constants and equilibrium constants of the kinetic model for $\mathrm{Ca}^{2+}$ dissociation}

The supercript $\mathrm{C}$ denotes binding to a $\mathrm{Ca}^{2+}$-binding site. Parameters describing binding to the 'gating' site are given in Table 1 of Henderson et al. (1994).

\begin{tabular}{|c|c|c|c|c|}
\hline \multirow[b]{2}{*}{ Reaction step } & \multicolumn{2}{|l|}{ Off rate } & \multicolumn{2}{|c|}{ Equilibrium } \\
\hline & Symbol* & Value $\left(\mathrm{s}^{-1}\right)$ & Symbol & Value \\
\hline $\mathrm{E}^{\prime}{ }^{\prime} \mathrm{Ca}_{2} \mathrm{HMg} \rightarrow \mathrm{E} 1^{\prime} \mathrm{CaHMg}$ & $\mathrm{IE} 1 \mathrm{HMg}^{7}$ & 12.9 & $K_{c 2 x}$ & $1.3 \times 10^{10} \mathrm{M}^{-1}$ \\
\hline $\mathrm{E}^{\prime} \mathrm{Ca}_{2} \mathrm{H} \rightarrow \mathrm{E}^{\prime} \mathrm{CaH}$ & $\mathrm{IE} 1 \mathrm{H}^{7}$ & 19.1 & $k_{c 2 x}^{2 x}$ & $1.3 \times 10^{10} \mathrm{M}^{-1}$ \\
\hline $\mathrm{E}^{\prime} \mathrm{Ca}_{2}^{\prime} \rightarrow \mathrm{E} 1^{\prime} \mathrm{Ca}$ & $\mathrm{rE} 1^{7}$ & 200 & $K_{c 2 x}$ & $1.3 \times 10^{10} \mathrm{M}^{-1}$ \\
\hline $\mathrm{E}^{\prime} \mathrm{Ca}_{2} \mathrm{Mg} \rightarrow \mathrm{E}^{\prime} \mathrm{C}_{2} \mathrm{Mg}$ & $\mathrm{rE} 1 \mathrm{Mg}^{7}$ & 2700 & $K_{c 2 x}^{2 x}$ & $1.3 \times 10^{10} \mathrm{M}^{-1}$ \\
\hline $\mathrm{E} 1^{\prime} \mathrm{CaHMg} \rightarrow \mathrm{E} 1 \mathrm{CaHMg}$ & $\mathrm{rE} 1 \mathrm{HMg} \mathrm{g}^{6}$ & 60 & $K_{c 3}$ & 1.0 \\
\hline $\mathrm{E} 1^{\prime} \mathrm{CaH} \rightarrow \mathrm{E} 1 \mathrm{CaH}$ & $\mathrm{rE} 1 \mathrm{H}^{6}$ & 150 & $K_{\mathrm{co}}$ & 1.0 \\
\hline $\mathrm{E} 1^{\prime} \mathrm{Ca} \rightarrow \mathrm{E} 1 \mathrm{Ca}$ & $\mathrm{rE} 1^{6}$ & 150 & $K_{c 3}^{\omega}$ & 1.0 \\
\hline $\mathrm{E}^{\prime} \mathrm{CaMg} \rightarrow \mathrm{E} 1 \mathrm{Ca} \mathrm{M} M \mathrm{~g}$ & $\mathrm{rE} 1 \mathrm{Mg}^{6}$ & 0 & $K_{\mathrm{c} 3}$ & 1.0 \\
\hline $\mathrm{E} 1 \mathrm{CaHMg} \rightarrow \mathrm{E} 1 \mathrm{HMg}$ & $\mathrm{rE} 1 \mathrm{HMg} \mathrm{g}^{5}$ & 12.9 & $K_{\mathrm{clc}}^{\omega}$ & $3.5 \times 10^{8} \mathrm{M}^{-1}$ \\
\hline $\mathrm{E} 1 \mathrm{CaH} \rightarrow \mathrm{E} 1 \mathrm{H}$ & $\mathrm{rE} 1 \mathrm{H}^{5}$ & 12.9 & $K_{c 1 b}$ & $3.5 \times 10^{8} \mathrm{M}^{-1}$ \\
\hline $\mathrm{E} 1 \mathrm{Ca} \rightarrow \mathrm{E} 1$ & $r E 1^{5}$ & 100.0 & $K_{\mathrm{cla}}$ & $5.8 \times 10^{6} \mathrm{M}^{-1}$ \\
\hline $\mathrm{E} 1 \mathrm{CaMg} \rightarrow \mathrm{E} 1 \mathrm{Mg}$ & $\mathrm{rE} 1 \mathrm{Mg}^{5}$ & 675 & $K_{\text {cld }}^{\text {ndd }}$ & $5.8 \times 10^{6} \mathrm{M}^{-1}$ \\
\hline $\mathrm{E} 1 \mathrm{Mg}^{\mathrm{C}} \rightarrow \mathrm{E} 1$ & $k_{3 b}$ & $1000 \dagger$ & $K_{\mathrm{Mg} 1}$ & {$\left[K_{\mathrm{c} 1} / 2000\right] \ddagger ., K_{\mathrm{c} 1} / 667 \S$} \\
\hline $\mathrm{E} 2 \mathrm{Mg}^{\mathrm{C}} \rightarrow \mathrm{E} 1$ & $k_{4 b}$ & {$[0.1] \ddagger .1000 \S$} & $K_{\mathrm{Mg} 2}^{\mathrm{mg1}}$ & $K_{\mathrm{cl}} / 1.0 \times 10^{4}$ \\
\hline $\mathrm{E} 2 \rightarrow \mathrm{E} 1$ & $k_{1 \mathrm{a}}$ & 80.0 & $K_{1}$ & 4.0 \\
\hline $\mathrm{E} 2 \mathrm{H} \rightarrow \mathrm{E} 1 \mathrm{H}$ & $k_{100}$ & 2.0 & $K_{2}$ & $6.67 \times 10^{-3}$ \\
\hline $\mathrm{E} 2 \mathrm{Mg}^{\mathrm{C}} \rightarrow \mathrm{E} 1 \mathrm{Mg}^{\mathrm{C}}$ & $k_{21}$ & $k_{1 f}$ & $K_{3}$ & $K_{1} K_{M g 1} / K_{M g 2}$ \\
\hline
\end{tabular}

* Superscript 7 refers to the $\mathrm{E1}^{\prime} \mathrm{Ca}_{2} \rightarrow \mathrm{E1}{ }^{\prime} \mathrm{Ca}$ step (Scheme 4), superscript 6 refers to the E1'Ca $\rightarrow$ E1Ca step (Scheme 5) and superscript 5 refers to the E1Ca $\rightarrow$ E1 step (Scheme 6). $\dagger$ Assumed fast and set to $1000 \mathrm{~s}^{-1}$.

$\ddagger$ Using the binding constant for $\mathrm{Mg}^{2+}$ estimated for NBD-labelled ATPase (Henderson et al., 1994).

$\S$ Using the alternative binding constant for $\mathrm{Mg}^{2+}$ (see the text).

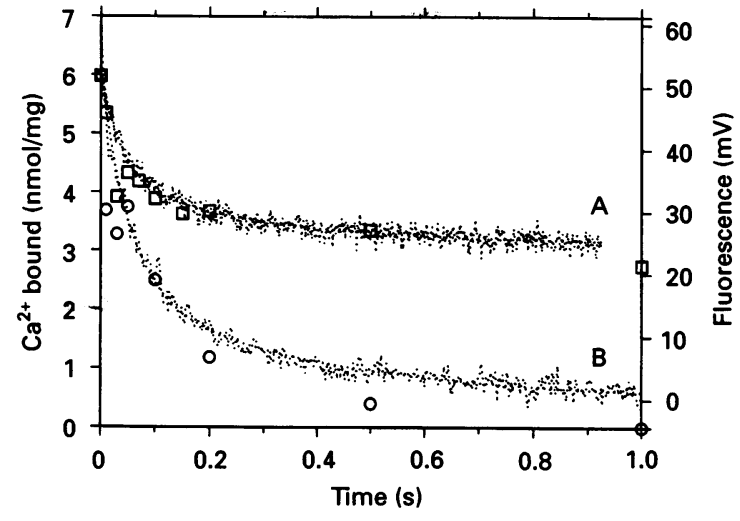

Figure 2 Effect of $\mathrm{Pr}^{3+}$ on the rate of dissociation of ${ }^{45} \mathrm{Ca}^{2+}$ and on the change in tryptophan-fluorescence intensity

The symbols $(O, \square)$ show the dissociation of ${ }^{45} \mathrm{Ca}^{2+}$ (nmok/mg of protein) when the ATPase incubated in buffer (150 mM Mops, $80 \mathrm{mM}$ Tris, pH 7.2) containing $50 \mu \mathrm{M}{ }^{45} \mathrm{Ca}^{2+}$ was pertused with the same buffer containing either $2 \mathrm{mM}$ EGTA $(O)$ or $0.1 \mathrm{mM} \mathrm{Pr}^{3+}(\square)$. The dotted lines show the decrease in tryptophan-fluorescence intensity $(\mathrm{mV})$ when the ATPase in buffer $\left(0.4 \mathrm{mg}\right.$ of protein/ml) containing $0.2 \mathrm{mM} \mathrm{Ca}^{2+}$ was mixed in a $1: 1$ ratio with the same buffer containing either $0.2 \mathrm{mM} \mathrm{Pr}^{3+}$ (curve A) or $2 \mathrm{mM}$ EGTA (curve B).

monoexponential; Figure 5 shows the effect of $\mathrm{Mg}^{2+}$ on this monoexponential rate.

\section{Effect of $\mathrm{Ca}^{2+}$ concentration on the tryptophan-fluorescence changes accompanying $\mathrm{Ca}^{2+}$ dissociation}

Figure 6 shows data recorded at $\mathrm{pH} 6.0$ as a function of final $\mathrm{pCa}$ value. It is clear that with increasing $\mathrm{Ca}^{2+}$ concentration both the rate and the amplitude of the change decrease. At high pCa values, a small rapid initial decrease in fluorescence intensity is observed, followed by a larger and slower change. The slow phase fits well to a single exponential, and the presence of the small fast phase has little effect on the goodness of fit. The rates and amplitudes obtained by fitting the data to single exponentials are shown in Figure 7 for data obtained at pH 6.0 and 7.2 in the absence of $\mathrm{Mg}^{2+}$ and at $\mathrm{pH} 6.0$ in the presence of $20 \mathrm{mM} \mathrm{Mg}^{2+}$.

\section{Other effects on the tryptophan-fluorescence changes accompanying $\mathrm{Ca}^{2+}$ dissociation}

The effect of temperature on the rate of the fluorescence change after the mixing of $\mathrm{Ca}^{2+}$-bound ATPase with EGTA at pH 7.2 was studied (Figure 8). In the absence of $\mathrm{Mg}^{2+}$, the data were fitted to a single exponential at all temperatures, and the rates gave a linear Arrhenius plot with an activation energy of $54.6 \pm 2.5 \mathrm{~kJ} \cdot \mathrm{mol}^{-1}$. In the presence of $20 \mathrm{mM} \mathrm{Mg}^{2+}$, the data at all temperatures fitted to the sum of two exponentials of equal amplitude, each component giving linear Arrhenius plots with activation energies of $57.3 \pm 3.8 \mathrm{~kJ} \cdot \mathrm{mol}^{-1}$ and $47.0 \pm 1.2 \mathrm{~kJ} \cdot \mathrm{mol}^{-1}$ respectively for the fast and slow components (Figure 8). Comparison of these activation energies with that expected for passive ion diffusion through a channel $\left(16 \mathrm{~kJ} \cdot \mathrm{mol}^{-1}\right.$; Hille, 1984) suggests that access to the $\mathrm{Ca}^{2+}$-binding sites is controlled by conformational changes on the ATPase.

Figure 9 shows the results of a $\mathrm{pH}$-jump experiment in which the $\mathrm{pH}$ was jumped simultaneously with mixing with $2 \mathrm{mM}$ EGTA in the presence of $\mathrm{Mg}^{2+}$. The rate of the fluorescence change observed on jumping the $\mathrm{pH}$ from 8.5 to 6.0 was identical with that observed when the ATPase was incubated in pH 6.0 buffer and mixed with EGTA to give a final pCa value of 5.4 (Figure 7), and the rate of the fluorescence change observed on jumping the $\mathrm{pH}$ from 6.0 to 8.5 was identical with that observed when the ATPase was incubated in pH 8.5 buffer (see Figure 3). Similarly, in the absence of $\mathrm{Mg}^{2+}, \mathrm{pH}$ jumps from 8.5 to 6.0 or 

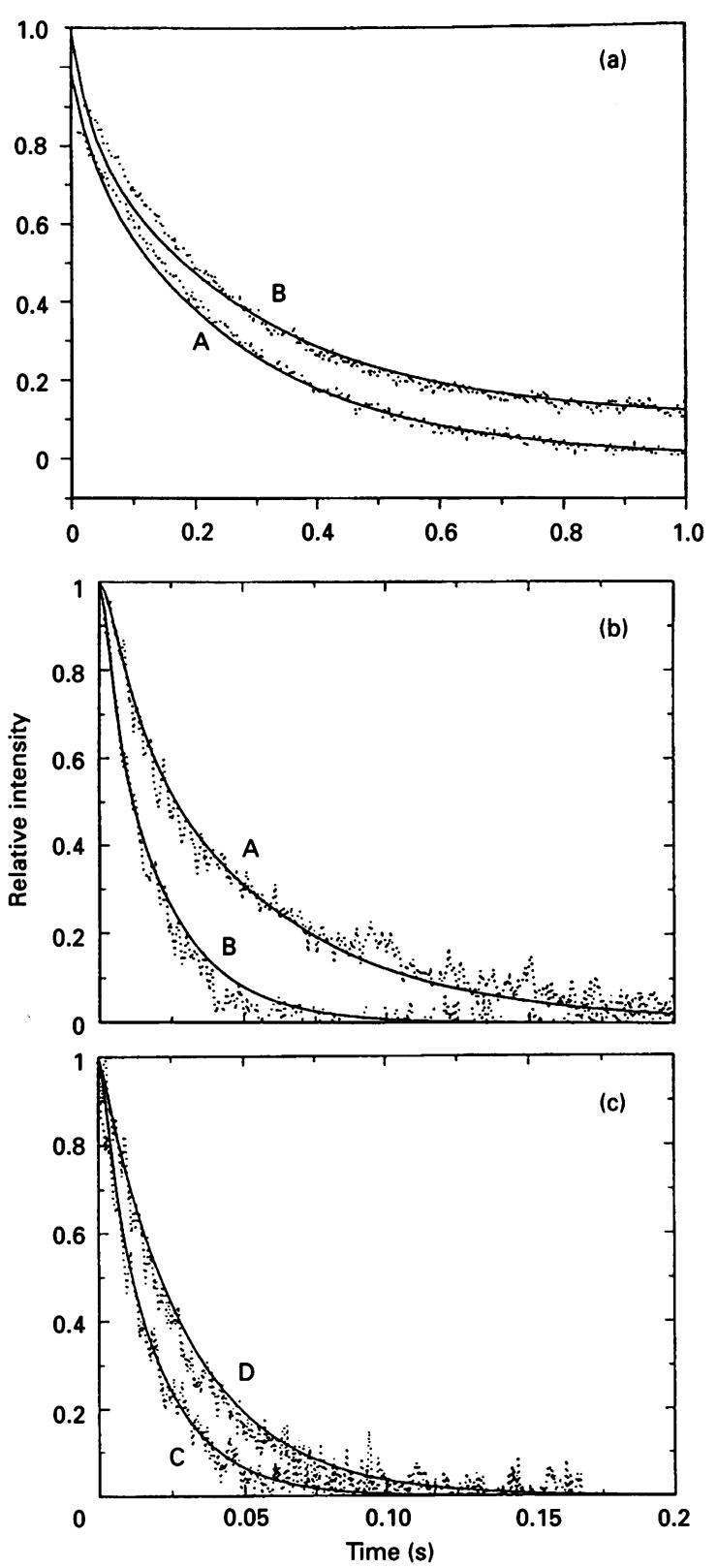

Figure 3 Kinetics of the decrease in tryptophan fluorescence caused by $\mathrm{Ca}^{2+}$ dissociation from the ATPase

The decrease in tryptophan fluorescence was recorded at pH 6.0 (a) or $8.5(\mathbf{b}, \mathbf{c})$ : (a) in the absence (A) or presence (B) of $20 \mathrm{mM} \mathrm{Mg}^{2+} ;(\mathbf{b}, \mathbf{C})$ in the absence $(A)$ or presence of 1.0 (B), 2.5 (C) or 40 (D) $\mathrm{mM} \mathrm{Mg}^{2+}$. In (a) curve B has been offset by 0.1 for clarity. In the stoppedflow experiment, the enzyme syringe contained $0.4 \mathrm{mg} / \mathrm{ml}$ ATPase in buffer at pH $6.0(130 \mathrm{mM}$ Mes, $50 \mathrm{mM}$ Tris) or pH 8.5 (27 mM Mes, $100 \mathrm{mM}$ Tris) containing $100 \mu \mathrm{M} \mathrm{Ca}^{2+}$ and the indicated concentration of $\mathrm{Mg}^{2+}$. The substrate syringe contained $20 \mathrm{mM}$ (pH 6.0) or $2 \mathrm{mM}$ EGTA (pH 8.5) in the same buffer. The contents of the two syringes were mixed in a 1:1 ratio to give final $\mathrm{pCa}$ values of 6.4 and 10.3 at $\mathrm{pH} 6.0$ and 8.5 respectively. The solid lines show simulations calculated by using the rate constants given in Table 1 .

from 6.0 to 8.5 gave traces identical with those obtained when the ATPase was incubated in buffer at $\mathrm{pH} 6.0$ or 8.5 (results not shown). The rates of binding and dissociation of $\mathrm{H}^{+}$are therefore fast compared with the rates of the other processes involved in $\mathrm{Ca}^{2+}$ dissociation, and thus effects due to $\mathrm{H}^{+}$can be treated by the quasiequilibrium approach.

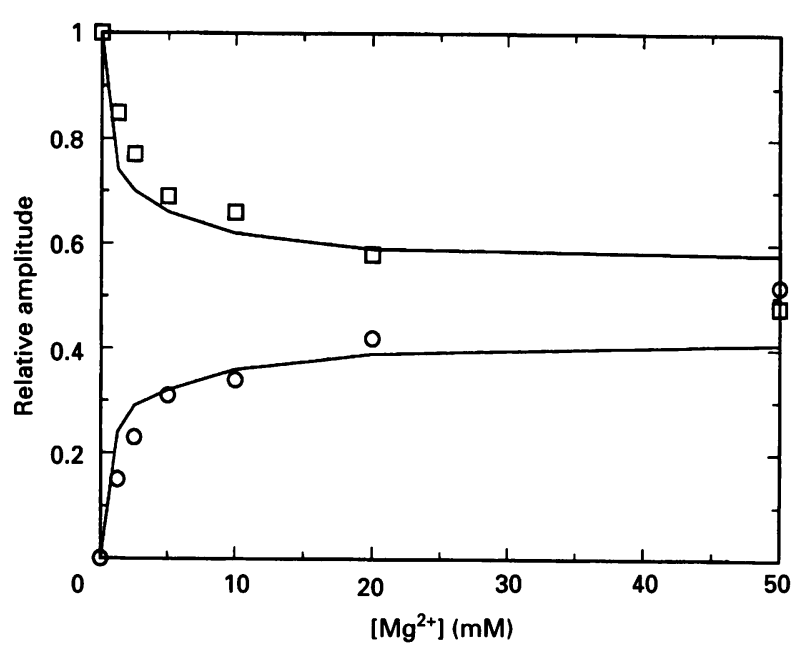

Figure 4 Effect of $\mathrm{Mg}^{2+}$ concentration on the relative amplitudes of the two components of the decrease in tryptophan fluorescence caused by $\mathrm{Ca}^{2+}$ dissociation from the ATPase at $\mathrm{pH} \mathbf{7 . 2}$

Measurements were performed as described in the legend to Figure 3 . The experimental data were fitted to the sum of two exponentials with the rate constant of the fast component fixed at $50 \mathrm{~s}^{-1}$. The relative amplitudes of the slow $(\square)$ and fast $(O)$ components are plotted against $\mathrm{Mg}^{2+}$ concentration (mM). The solid lines show the variation of the amplitudes of the slow and fast components obtained when theoretical simulations calculated by using the parameters in Table 1 are fitted in the same way to the sum of two exponentials.

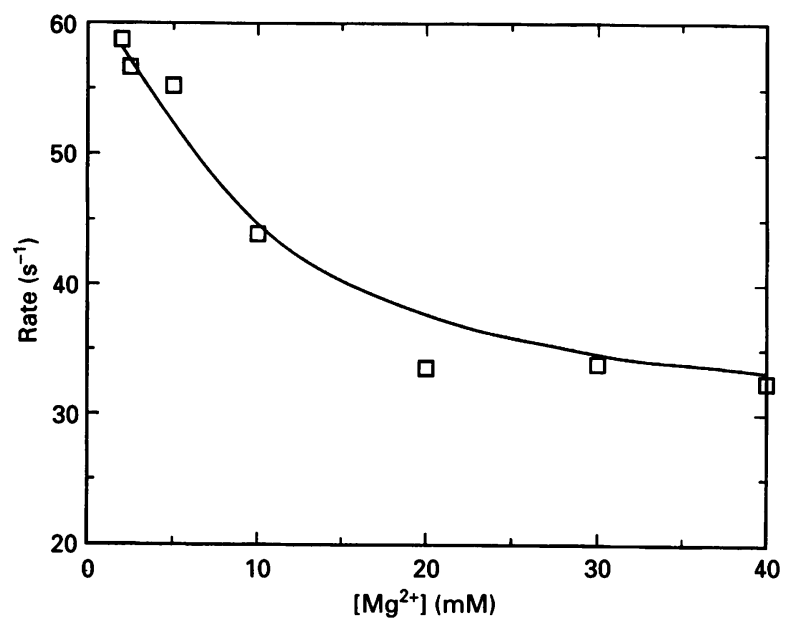

Figure 5 Effect of $\mathrm{Mg}^{2+}$ on the rate of decrease in tryptophan fluorescence caused by $\mathrm{Ca}^{2+}$ dissociation from the ATPase at $\mathrm{pH} 8.5$

Measurements were performed as described in the legend to Figure 3 . The experimental data for $\mathrm{Mg}^{2+}$ concentrations of $2.0 \mathrm{mM}$ or greater were fitted to a single exponential and the rate plotted $(\square)$. The solid line shows the variation in rate obtained when theoretical simulations calculated by using the parameters in Table 1 are fitted in the same way.

Experiments in which the $\mathrm{Mg}^{2+}$ concentration was jumped suggest that the $\mathrm{Mg}^{2+}$-binding steps affecting $\mathrm{Ca}^{2+}$ dissociation are also fast. Thus fluorescence changes observed when the $\mathrm{Ca}^{2+}$ bound ATPase incubated in the absence of $\mathrm{Mg}^{2+}$ at $\mathrm{pH} 7.2$ were mixed in a $1: 1$ ratio with buffer containing EGTA and $20 \mathrm{mM}$ $\mathrm{Mg}^{2+}$ were identical with those obtained when the $\mathrm{Ca}^{2+}$-bound ATPase was incubated in buffer containing $10 \mathrm{mM} \mathrm{Mg}^{2+}$ and mixed with buffer containing EGTA and $10 \mathrm{mM} \mathrm{Mg}^{2+}$ (results not shown). 


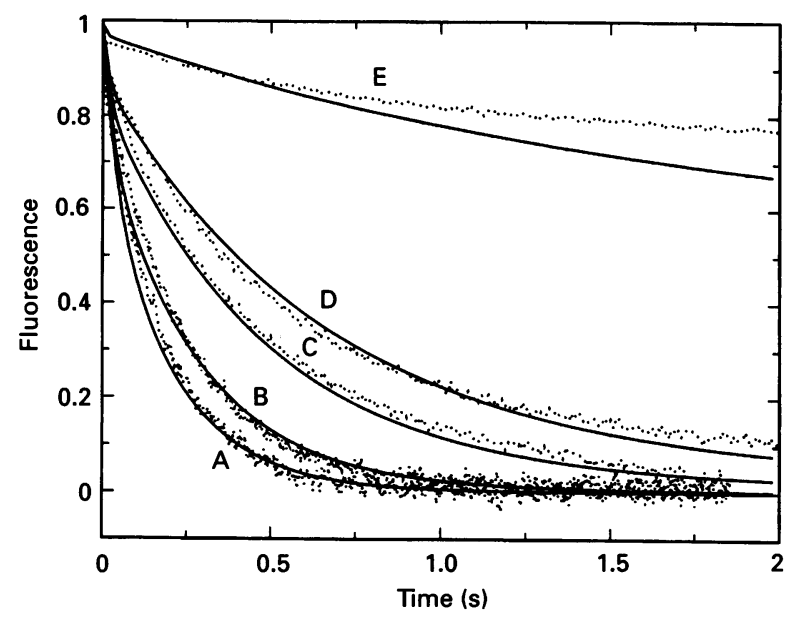

Figure 6 Effect of $\mathrm{Ca}^{2+}$ concentration on the kinetics of the decrease in tryptophan fluorescence caused by $\mathrm{Ca}^{2+}$ dissociation from the ATPase at pH 6.0 in the presence of $20 \mathrm{mM} \mathrm{Mg}{ }^{2+}$

In the stopped-flow experiment the enzyme syringe contained $0.4 \mathrm{mg} / \mathrm{ml}$ ATPase in buffer (130 mM Mes, $50 \mathrm{mM}$ Tris, pH 7.2) containing $100 \mu \mathrm{M} \mathrm{Ca}^{2+}$ and $20 \mathrm{mM} \mathrm{Mg}{ }^{2+}$. The substrate syringe contained $20 \mathrm{mM} \mathrm{Mg}{ }^{2+}$ in the same buffer and a concentration of EGTA to give after $1: 1$ mixing a final $\mathrm{pCa}$ of: $\mathrm{A}, 6.92 ; \mathrm{B}, 6.22 ; \mathrm{C}, 5.71 ; \mathrm{D}, 5.48 ; \mathrm{E}, 4.7$. The dotted lines show the observed decreases in tryptophan fluorescence and the solid lines show simulations calculated by using the parameters in Table 1 .

\section{The rate of change of NBD fluorescence for NBD-labelled ATPase}

The fluorescence intensity of the ATPase labelled with 4nitrobenzo-2-oxa-1,3-diazole (NBD) is low in the E2 state (predominant at low $\mathrm{pH}$ ) and high in the E1 state (predominant at high pH) (Wakabayashi et al., 1990; Henderson et al., 1994). Figure 10 shows the change in NBD fluorescence intensity observed when the $\mathrm{pH}$ of the ATPase incubated in EGTA is jumped from 6.0 to 8.5. The specific inhibitors, thapsigargin and trilobolide, shift the E2-E1 equilibrium strongly towards E2 at all $\mathrm{pH}$ values. As the $\mathrm{pH}$-dependence of the rate of the fluorescence change (Figure 11) is identical with the $\mathrm{pH}$-dependence of the E1/E2 equilibrium [see (Henderson et al., 1994)], we have suggested that the $\mathrm{pH}$-dependence of the $\mathrm{E} 2_{\text {thapsigargin }} \rightarrow$ $\mathrm{E} 1_{\text {thapsigargin }}$ transition is defined by the $\mathrm{pH}$-dependence of the E2 $\rightarrow$ E1 transition (Wictome et al., 1992a,b). The rate of the response to $\mathrm{Ca}^{2+}$ is shown as a function of $\mathrm{pH}$ in Figure 11 for the ATPase incubated with a 1:1 molar ratio of thapsigargin or trilobolide.

The E1/E2 equilibrium of the ATPase can be described by Scheme 2 . Treating $\mathrm{H}^{+}$binding by the quasiequilibrium approach, the effective rate of the $\mathrm{E} 2 \rightarrow \mathrm{E} 1$ transition, $k_{1 \mathrm{f}}{ }^{\text {eff }}$, can be written as:

$$
k_{1 \mathrm{f}}{ }^{\text {eff }}=\frac{k_{1 \mathrm{fa}}}{\left(1+K_{\mathrm{H} 7}\right)\left[\mathrm{H}^{+}\right]}+\frac{k_{1 \mathrm{pb}} K_{\mathrm{H} 7}\left[\mathrm{H}^{+}\right]}{\left(1+K_{\mathrm{H} 7}\right)\left[\mathrm{H}^{+}\right]}
$$

where the values of $K_{\mathrm{H} 7}$ and the equilibrium constants $k_{1 \mathrm{fa}} / k_{1 \mathrm{ba}}$ $\left(K_{1}\right)$ and $k_{1 \mathrm{fb}} / k_{1 \mathrm{bb}}$ have been defined by the equilibrium experiments reported in the preceding paper (Henderson et al., 1994). The experiment shown in Figure 10 in the absence of $\mathrm{Mg}^{2+}$ defines the value of $k_{1 \mathrm{f}}{ }^{\text {eff }}$ at $\mathrm{pH} \mathrm{8.5}$, and the experiments in Figure 11 define its $\mathrm{pH}$-dependence. As shown, the data fit with values of 80.0 and 2.0 for $k_{1 \mathrm{fa}}$ and $k_{1 \mathrm{pb}}$ respectively, assuming decreases

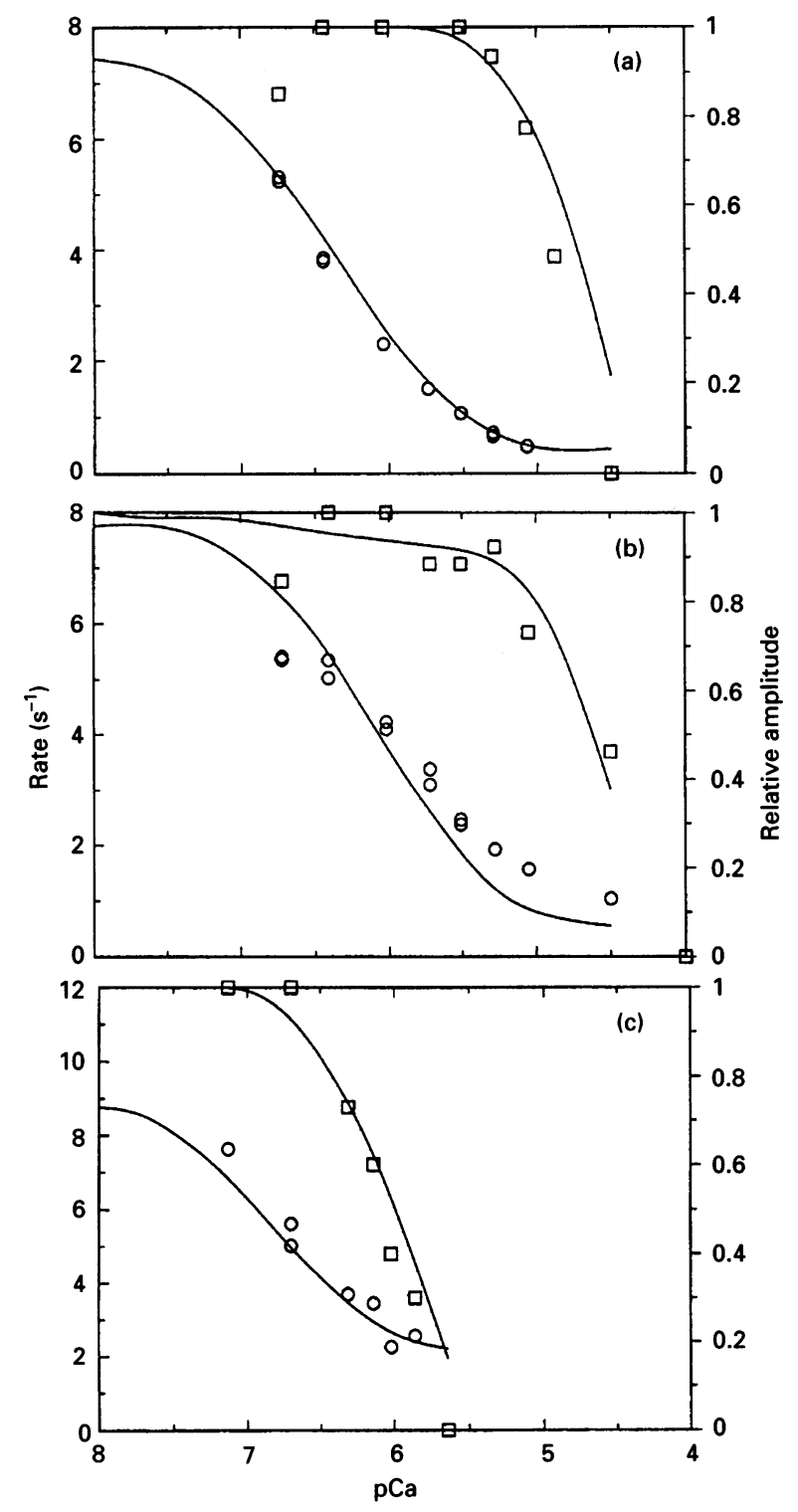

Figure 7 Effect of $\mathrm{pCa}$ on the rates and relative amplitudes of the fluorescence changes caused by $\mathrm{Ca}^{2+}$ dissociation from the ATPase

Measurements were performed as described in the legend to Figure 3 at $\mathrm{pH} 6.0(\mathbf{a}, \mathbf{b})$ in buffer (130 mM Mes, $50 \mathrm{mM}$ Tris) in the absence (a) or presence (b) of $20 \mathrm{mM} \mathrm{Mg}{ }^{2+}$ or $\mathrm{pH} 7.2$ (c) in buffer (130 mM Mes, $50 \mathrm{mM}$ Tris, pH 7.2). Data were fitted to single exponentials and the calculated rates $(O)$ and amplitudes $(\square)$ are plotted as a function of pCa. The solid lines show the variation of rates and amplitudes with $\mathrm{pCa}$ obtained when theoretical simulations calculated by using the parameters in Table 1 are fitted in the same way to single exponentials; for the data at $\mathrm{pH} 7.2$, a binding constant $K_{\mathrm{c} 2 \mathrm{x}}$ half that in Table 1 was assumed (see the Discussion section).

in $k_{1 \mathrm{f}}{ }^{\text {eff }}$ by factors of 700 and 160 in the presence of thapsigargin and trilobolide $A$ respectively.

In the presence of $\mathrm{Mg}^{2+}$, the magnitude of the change in NBD fluorescence on jumping the $\mathrm{pH}$ from 6.0 to 8.5 is greater than in the absence of $\mathrm{Mg}^{2+}$ (Figure 10) because binding of $\mathbf{M g}^{2+}$ shifts the E1/E2 equilibrium towards E1 (Henderson et al., 1994). The effect of $\mathrm{Mg}^{2+}$ on the rate of the $\mathrm{E} 2 \rightarrow \mathrm{E} 1$ transition is best defined by its effect on the rate of $\mathrm{Ca}^{2+}$ binding at $\mathrm{pH} 7.2$ (see below). 


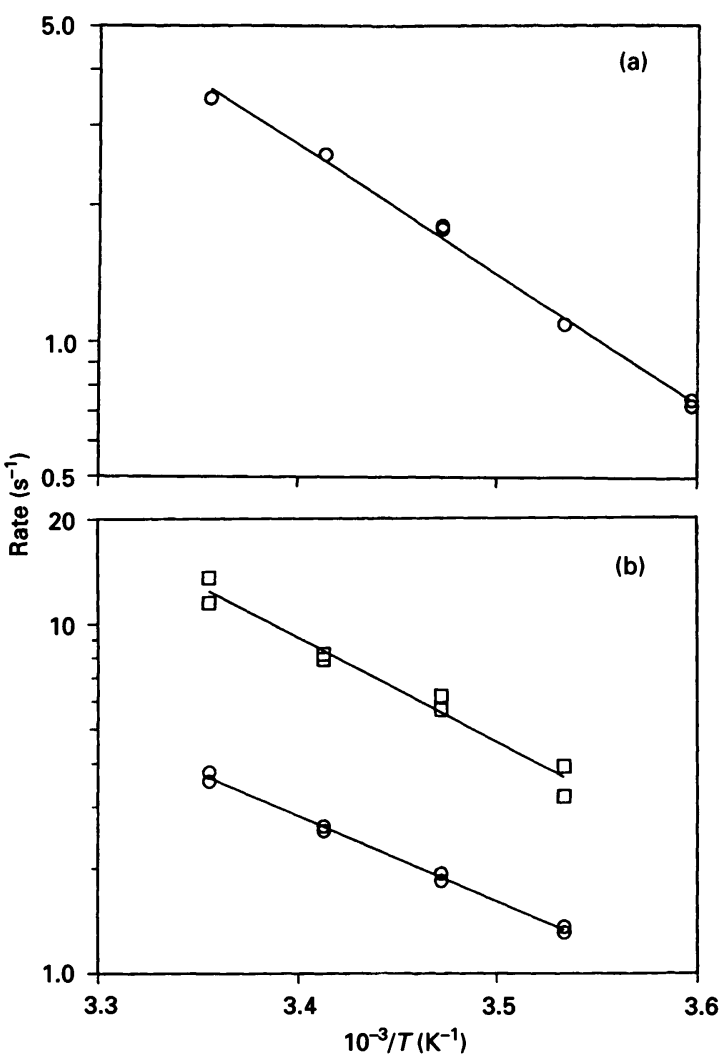

Figure 8 Arrhenius plots of the rates of the fluorescence change caused by $\mathrm{Ca}^{2+}$ dissociation at $\mathrm{pH} 7.2$

Measurements were performed as described in the legend to Figure 1: (a) data in the absence of $\mathrm{Mg}^{2+}$ were fitted to a single exponential and the rates plotted $(\mathrm{O})$; (b) data in the presence of $20 \mathrm{mM} \mathrm{Mg}{ }^{2+}$ were fitted to the sum of two exponentials with equal amplitudes and the rates of the fast $(\square)$ and slow $(O)$ components plotted.

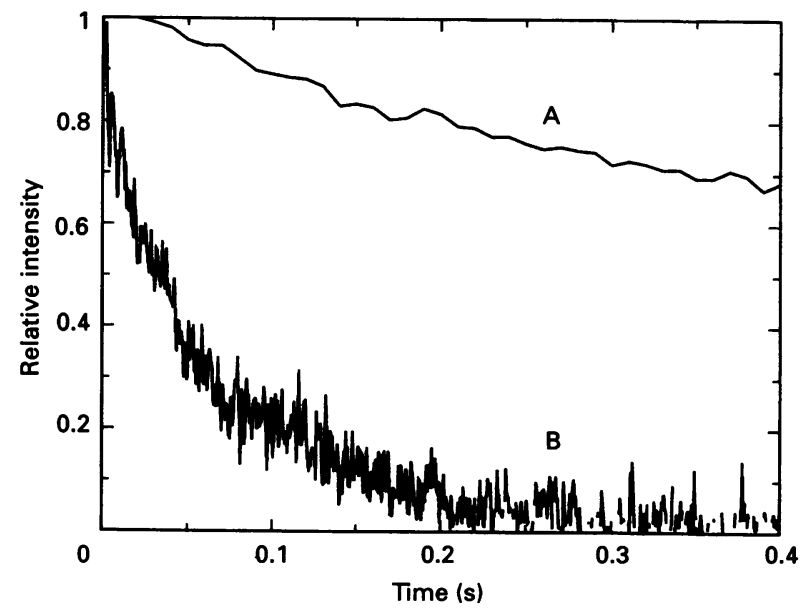

Flgure 9 Effect of a pH jump on the kinetics of the decrease in tryptophan fluorescence caused by $\mathrm{Ca}^{2+}$ dissoclation from the ATPase in the presence of $20 \mathrm{mM} \mathrm{Mg}{ }^{2+}$

The traces show the change in fluorescence intensity when the ATPase $(0.4 \mathrm{mg} / \mathrm{ml})$ in buffer ( $3 \mathrm{mM} \mathrm{Mes} /$ Tris) containing $100 \mu \mathrm{M} \mathrm{Ca}^{2+}$ at pH 8.5 (A) or 6.0 (B) is mixed in a $1: 1$ ratio with buffer containing $2 \mathrm{mM}$ EGTA: (A) $130 \mathrm{mM}$ Mes, $50 \mathrm{mM}$ Tris, pH 6.0; (B) $100 \mathrm{mM}$ Tris, $27 \mathrm{mM}$ Mes, pH 8.5. All buffers contained $20 \mathrm{mM} \mathrm{Mg}^{2+}$ and final pCa values were (A) 5.4 and (B) 8.4.

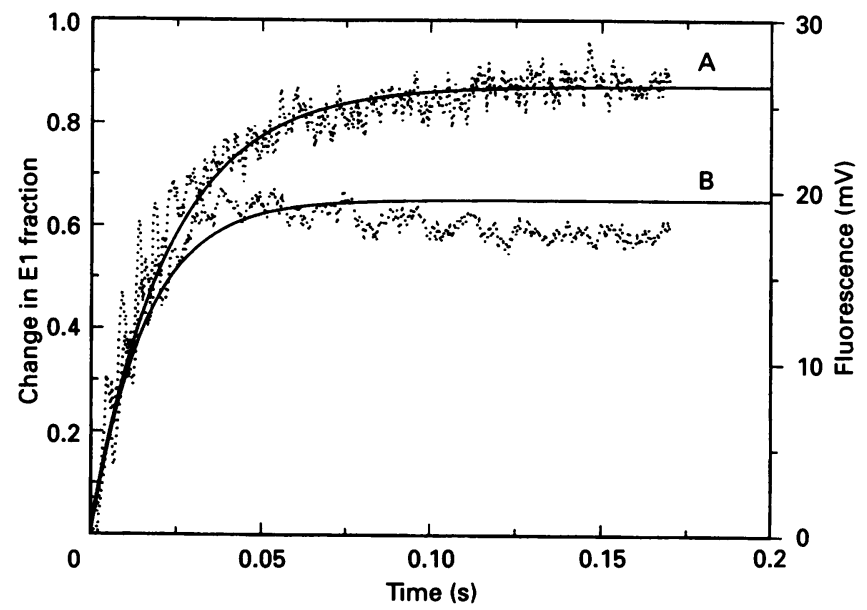

Figure 10 Effect of a pH jump on the fluorescence Intensity of NBDlabelled ATPase

The Figure shows the change in NBD fluorescence when NBD-labelled ATPase $(0.4 \mathrm{mg} / \mathrm{ml})$ in $\mathrm{pH} 6.0$ buffer ( $3 \mathrm{mM}$ Mes/Tris, $2 \mathrm{mM}$ EGTA) is mixed in a 1:1 molar ratio with $\mathrm{pH} 8.5$ buffer (100 mM Tris, $27 \mathrm{mM}$ Mes, $2 \mathrm{mM}$ EGTA). In experiment A, both buffers contained $20 \mathrm{mM}$ $\mathrm{Mg}^{2+}$ and in experiment $\mathrm{B}$ no $\mathrm{Mg}^{2+}$ was present. The solid lines are simulations of the change in the fraction of E1 forms of the ATPase calculated with the parameters given in Table 1. The data have been plotted so that a change in fluorescence intensity of $30 \mathrm{mV}$ corresponds to a calculated change in the E1 fraction of 1.0 .

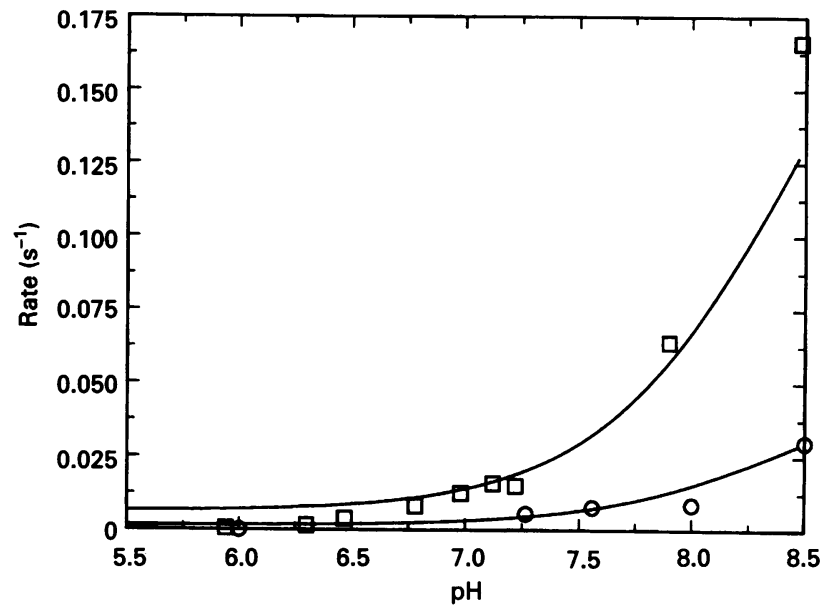

Figure 11 Effect of $\mathrm{pH}$ on the rate of increase in fluorescence intensity of NBD-labelled ATPase in the presence of inhibltors observed on addition of $\mathrm{Ca}^{2+}$

The increase in fluorescence intensity of NBD-labelled ATPase in buffer $(50 \mathrm{mM}$ Mes $/ \mathrm{KOH}$, $\mathrm{pH}$ 6.0-6.8; $50 \mathrm{mM}$ Hepes/KOH, $\mathrm{pH} 7.0-7.8 ; 50 \mathrm{mM}$ Tris/HCl, $\mathrm{pH} 8.0-8.5$ ) containing $0.3 \mathrm{mM}$ EGTA was observed after the addition of $\mathrm{Ca}^{2+}$ to a final concentration of $0.7 \mathrm{mM}$ in the presence of a 1:1 molar ratio of inhibitor/ATPase: $O$, thapsigargin; $\square$, trilobolide. The experimental curves were fitted to single exponentials and the rates are plotted as a function of $\mathrm{pH}$. The curves are the rates calculated by using the parameters in Table 1 , assuming decreases in the rate of the E2 $\rightarrow E 1$ transition by factors of 700 and 160 for thapsigargin and trilobolide respectively.

\section{Effect of $\mathrm{pH}$ and $\mathrm{Mg}^{2+}$ on the tryptophan-filuorescence changes accompanying $\mathrm{Ca}^{2+}$ binding}

As shown in Figure 12, the rate of the tryptophan-fluorescence change on the binding of $\mathrm{Ca}^{2+}$ to the ATPase increases markedly with increasing $\mathrm{pH}$. Also as shown, the presence of $20 \mathrm{mM} \mathrm{Mg}^{2+}$ 


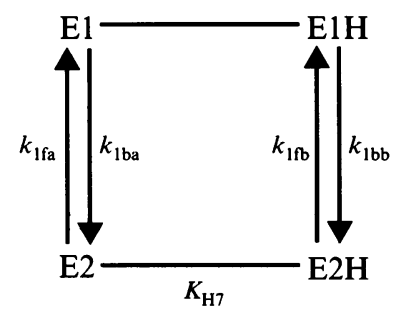

Scheme 2
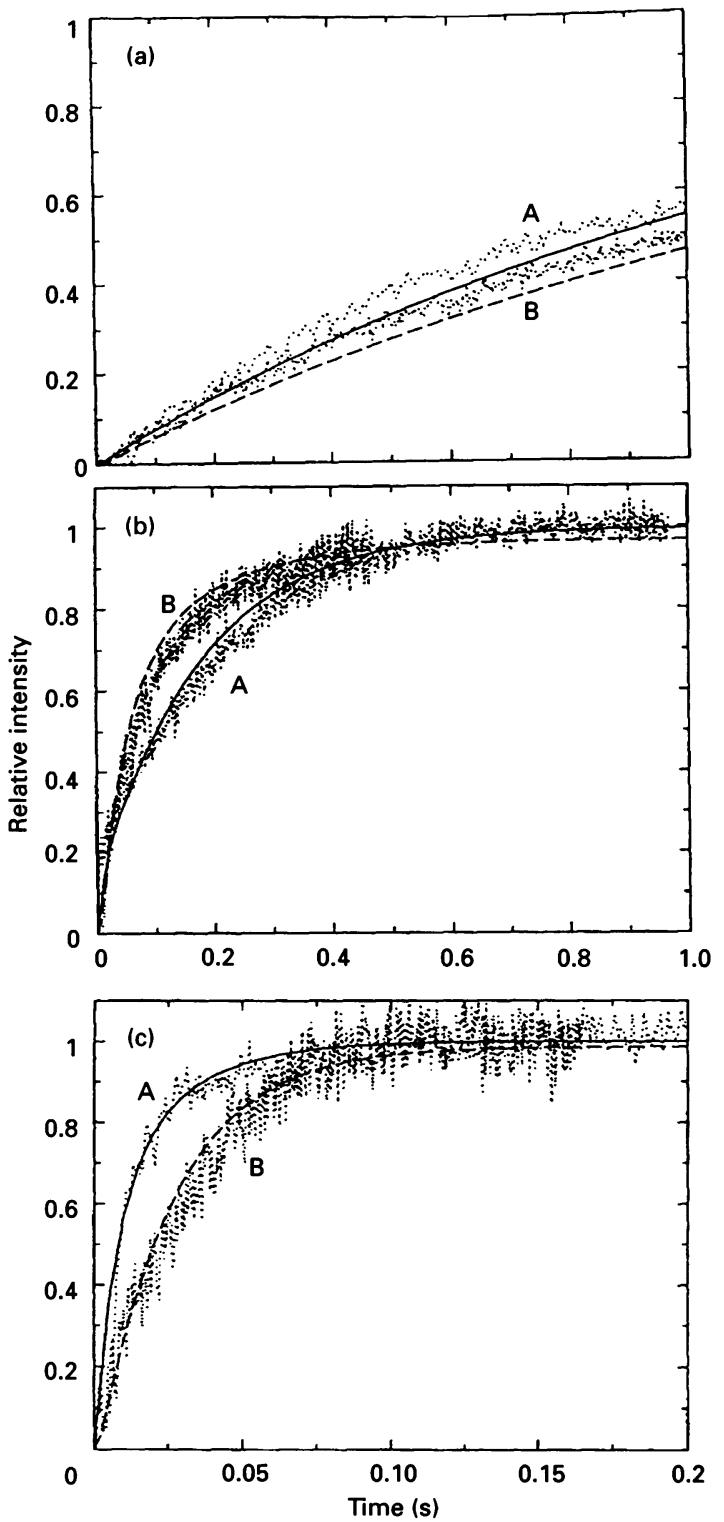

Figure 12 Effect of $\mathrm{pH}$ and $\mathrm{Mg}^{2+}$ on the kinetics of the increase in tryptophan fluorescence caused by $\mathrm{Ca}^{2+}$ binding

The Figure shows the increase in tryptophan fluorescence when ATPase $(0.4 \mathrm{mg} / \mathrm{ml})$ in buffer at (a) pH 6.0 (130 mM Mes, $50 \mathrm{mM}$ Tris), (b) pH 7.2 (150 mM Mops, $80 \mathrm{mM}$ Tris) or (c) $\mathrm{pH} 8.5$ (100 mM Tris, $27 \mathrm{mM}$ Mes) containing $0.2 \mathrm{mM}$ EGTA was mixed in a 1:1 ratio with the same buffer but containing $0.3 \mathrm{mM} \mathrm{Ca}^{2+}$. The dotted traces show experimental data in the absence (A) or presence (B) of $20 \mathrm{mM} \mathrm{Mg}^{2+}$. The solid and broken lines show simulations calculated using the parameters in Table 1 , in the presence or absence of $20 \mathrm{mM} \mathrm{Mg}^{2+}$ respectively.
Table 2 Rates describing tryptophan-fluorescence changes on $\mathrm{Ca}^{2+}$ binding

Rates were obtained by fitting the tryptophan-fluorescence curves and the simulations of $\mathrm{Ca}^{2+}$ binding at $\mathrm{pH} 7.2$ at the given $\mathrm{Mg}^{2+}$ concentrations to the sum of two exponentials.

\begin{tabular}{|c|c|c|c|c|c|c|c|c|}
\hline \multirow{3}{*}{$\begin{array}{l}{\left[\mathrm{Mg}^{2+}\right]} \\
(\mathrm{mM})\end{array}$} & \multicolumn{4}{|c|}{ Experimental } & \multicolumn{4}{|c|}{ Simulation } \\
\hline & \multicolumn{2}{|c|}{$k\left(s^{-1}\right)$} & \multicolumn{2}{|c|}{ Amplitude } & \multicolumn{2}{|c|}{$k\left(s^{-1}\right)$} & \multicolumn{2}{|c|}{ Amplitude } \\
\hline & Fast & Slow & Fast & Slow & Fast & Slow & Fast & Slow \\
\hline 2.5 & 6.3 & 49.0 & 0.67 & 0.31 & 6.2 & 57.0 & 0.68 & 0.31 \\
\hline 4.0 & 7.8 & 44.0 & 0.58 & 0.42 & 6.2 & 47.5 & 0.63 & 0.36 \\
\hline 6.0 & 8.0 & 53.0 & 0.57 & 0.43 & 6.2 & 41.0 & 0.59 & 0.41 \\
\hline 8.0 & 7.1 & 34.0 & 0.54 & 0.46 & 6.2 & 37.5 & 0.56 & 0.43 \\
\hline 10.0 & 6.7 & 37.2 & 0.52 & 0.48 & 6.2 & 35.0 & 0.53 & 0.46 \\
\hline
\end{tabular}

Table 3 Rates and amplitudes derived from fitting the tryptophan filuorescence changes on $\mathrm{Ca}^{2+}$ binding at $\mathrm{pH} 8.5$ and the indicated $\mathrm{Mg}^{2+}$ concentrations

\begin{tabular}{|c|c|c|c|}
\hline \multirow[b]{2}{*}[\mathrm{Mg}^{2+}]{$(\mathrm{mM})$} & \multicolumn{2}{|l|}{ Experimental } & \multirow{2}{*}{$\frac{\text { Simulation }}{k\left(s^{-1}\right)}$} \\
\hline & $k\left(s^{-1}\right)$ & Amplitude (mV) & \\
\hline 0 & $161,11.2^{*}$ & $100,100^{*}$ & - \\
\hline 0.1 & $138,10.6^{*}$ & $110,30^{\star}$ & - \\
\hline 0.5 & 106 & 110 & 102 \\
\hline 1.0 & 80 & 140 & 77.9 \\
\hline 2.0 & 74 & 160 & 72.6 \\
\hline 2.5 & 71 & 175 & 69.8 \\
\hline 5.0 & 55 & 200 & 58.7 \\
\hline 10.0 & 39 & 220 & 47.0 \\
\hline 20.0 & 35 & 200 & 37.3 \\
\hline
\end{tabular}

has little effect on the rate at $\mathrm{pH} 6.0$, increases it at $\mathrm{pH} 7.2$ and decreases it at $\mathrm{pH}$ 8.5. The fluorescence curves obtained at pH 6.0 in the presence or absence of $\mathrm{Mg}^{2+}$ fit to a single exponential with a rate constant of $1 \mathrm{~s}^{-1}$. At $\mathrm{pH} 7.2$ in the presence or absence of $\mathrm{Mg}^{2+}$, the data fit to the sum of two exponentials with the rate constants and amplitudes given in Table 2. The major effect of $\mathrm{Mg}^{2+}$ is to increase the amplitude of the fast component with a slight decrease in the rate of the fast component. At $\mathrm{pH} 8.5$ the effects of $\mathrm{Mg}^{2+}$ are more complex. In the absence of $\mathrm{Mg}^{2+}$ or at a $\mathrm{Mg}^{2+}$ concentration of $0.1 \mathrm{mM}$, the data fit to a sum of two exponentials but at higher $\mathbf{M g}^{2+}$ concentrations the fluorescence changes become monoexponential (Table 3).

Figure 13 shows the effect of a $\mathrm{pH}$ jump on the rate of the tryptophan-fluorescence change on $\mathrm{Ca}^{2+}$ binding. When the $\mathrm{pH}$ jump is performed from $\mathrm{pH} 8.5$ to 6.0 , an initial rapid phase is observed before the slower change typical of $\mathrm{pH} 6.0$ (Figure 13a). In contrast, when the pH is jumped from 6.0 to 8.5 in the presence of $20 \mathrm{mM} \mathrm{Mg}^{2+}$, an initial lag phase is observed (Figure 13b); a similar lag phase is observed in the absence of $\mathbf{M g}^{2+}$ (results not shown).

Figure 14 shows the results of experiments in which the $\mathrm{Mg}^{2+}$ concentration is jumped. At $\mathrm{pH} \mathrm{7.2,} \mathrm{the} \mathrm{rate} \mathrm{of} \mathrm{change} \mathrm{of}$ tryptophan fluorescence on binding $\mathrm{Ca}^{2+}$ after a jump in $\mathrm{Mg}^{2+}$ concentration from 0 to $20 \mathrm{mM}$ is slower than that observed for the ATPase preincubated with $20 \mathrm{mM} \mathrm{Mg}^{2+}$ (Figure 14a). At $\mathrm{pH} 8.5$, the rate of change of tryptophan fluorescence is the same 


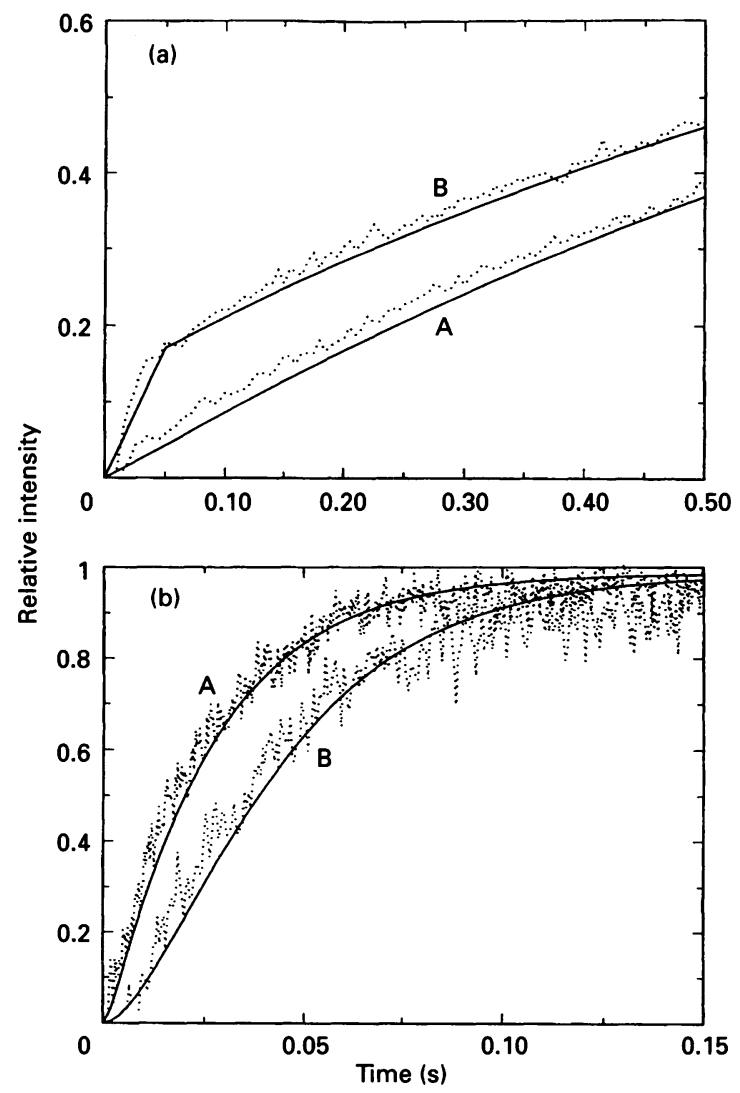

Figure 13 Effect of a pH jump on the kinetics of the increase in tryptophan fluorescence caused by $\mathrm{Ca}^{2+}$ binding to the ATPase

(a) Effect of a pH jump from 8.5 to 6 . In the control experiment (A) ATPase in pH 6.0 buffer (130 mM Mes, $50 \mathrm{mM}$ Tris) containing $0.2 \mathrm{mM}$ EGTA was mixed in a 1:1 ratio with the same buffer containing $0.3 \mathrm{mM} \mathrm{Ca}^{2+}$. In the pH-jump experiment (B) ATPase in pH 8.5 buffer $(3 \mathrm{mM}$ Tris/Mes) containing $0.2 \mathrm{mM}$ EGTA was mixed in a $1: 1$ ratio with $\mathrm{pH} 6.0$ buffer $(130 \mathrm{mM}$ Mes, $50 \mathrm{mM}$ Tris) containing $0.3 \mathrm{mM} \mathrm{Ca}^{2+}$. (b) Effect of a pH jump from 6.0 to 8.5 . In the control experiment (A) ATPase in pH 8.5 buffer (100 mM Tris, $27 \mathrm{mM} \mathrm{Mes,} 20 \mathrm{mM} \mathrm{Mg}^{2+}$ ) containing $0.2 \mathrm{mM}$ EGTA was mixed in a 1:1 ratio with the same buffer containing $0.3 \mathrm{mM}$ $\mathrm{Ca}^{2+}$. In the pH-jump experiment (B) ATPase in pH 6.0 buffer ( $\left.3 \mathrm{mM} \mathrm{Mes} / \mathrm{Tris}, 20 \mathrm{mM} \mathrm{Mg}^{2+}\right)$ was mixed in a 1:1 ratio with pH 8.5 buffer (100 mM Tris, $27 \mathrm{mM} \mathrm{Mes,} 20 \mathrm{mM} \mathrm{Mg}^{2+}$ ) containing $0.3 \mathrm{mM} \mathrm{Ca}^{2+}$. The dotted lines show the experimental data and the solid lines show simulations calculated using the parameters in Table 1.

for a jump in $\mathrm{Mg}^{2+}$ concentration from 0 to $20 \mathrm{mM}$ or after preincubation of the ATPase with $20 \mathrm{mM} \mathrm{Mg}{ }^{2+}$. Similarly, at pH 6.0, identical responses are obtained on binding $\mathrm{Ca}^{2+}$ either with a jump in $\mathrm{Mg}^{2+}$ concentration or after preincubation with $\mathrm{Mg}^{2+}$ (results not shown).

\section{DISCUSSION}

In the preceding paper (Henderson et al., 1994), a model was presented for equilibrium binding of $\mathrm{Ca}^{2+}$ to the $\left(\mathrm{Ca}^{2+}-\mathrm{Mg}^{2+}\right)$ ATPase. This model is now used to interpret studies of the kinetics of $\mathrm{Ca}^{2+}$ binding and dissociation. The model proposes binding of $\mathrm{Ca}^{2+}$ to two sites on the ATPase, in competition with binding of $\mathrm{H}^{+}$and $\mathrm{Mg}^{2+}$ at both sites. A third site, referred to as the 'gating' site, binds $\mathrm{H}^{+}$and $\mathrm{Mg}^{2+}$, affecting $\mathrm{Ca}^{2+}$ binding; binding constants for $\mathrm{H}^{+}$and $\mathrm{Mg}^{2+}$ at the 'gating' site were obtained by analysis of fluorescence experiments with the ATPase
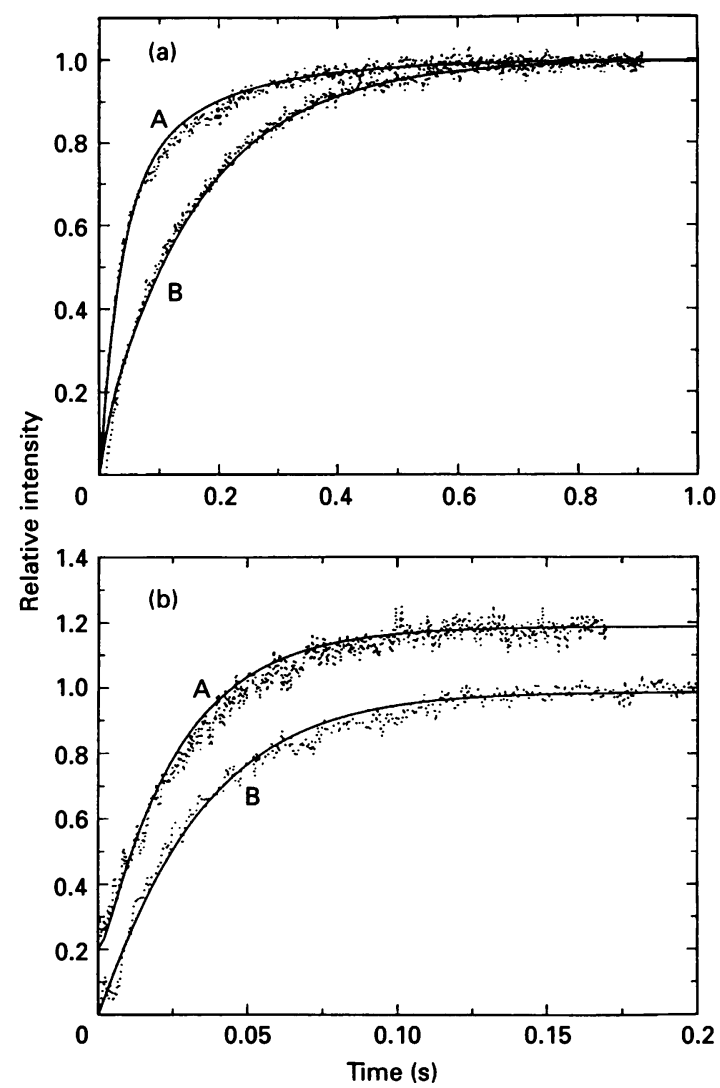

Figure 14 Effect of a jump in $\mathrm{Mg}^{2+}$ concentration from 0 to $20 \mathrm{mM}$ on the kinetics of the increase in tryptophan fluorescence caused by $\mathrm{Ca}^{2+}$ binding to the ATPase

Experiments were performed at pH 7.2 (a) or 8.5 (b). In the control experiments (A) ATPase in buffer (150 mM Mops, $80 \mathrm{mM}$ Tris, pH 7.2 or $100 \mathrm{mM}$ Tris, $27 \mathrm{mM}$ Mes, pH 8.5) containing $0.2 \mathrm{mM}$ EGTA and $20 \mathrm{mM} \mathrm{Mg}{ }^{2+}$ was mixed in a $1: 1$ ratio with the same buffer containing $0.3 \mathrm{mM} \mathrm{Ca}^{2+}$. In the $\mathrm{Mg}^{2+}$ jump experiments (B) the ATPase incubated in buffer containing $0.2 \mathrm{mM}$ EGTA in the absence of $\mathrm{Mg}^{2+}$ was mixed in a 1:1 ratio with the same buffer containing $0.3 \mathrm{mM} \mathrm{Ca}^{2+}$ and $40 \mathrm{mM} \mathrm{Mg}^{2+}$. In (b) the upper trace has been offset by 0.2 for clarity. The dotted lines show experimental traces and the solid lines show simulations calculated using the parameters in Table 1.

labelled with 4-(bromomethyl)-6,7-dimethoxycoumarin. Finally, it was proposed that the ATPase could exist in two conformational states: $\mathrm{E} 1$ with high-affinity binding sites for $\mathrm{Ca}^{2+}$ exposed to the cytoplasm and $\mathrm{E} 2$ unable to bind $\mathrm{Ca}^{2+}$ to cytoplasmic sites, with the equilibrium between $\mathrm{E} 1$ and $\mathrm{E} 2$ being dependent on protonation of a single residue on the ATPase [see Figure 9 in Henderson et al. (1994)].

\section{Nature of the tryptophan-filuorescence change}

At $\mathrm{pH} 7.2$ in the absence of $\mathrm{Mg}^{2+}$, dissociation of ${ }^{45} \mathrm{Ca}^{2+}$ from the $\mathrm{Ca}^{2+}$-bound ATPase fits well to a single exponential, but in the presence of $20 \mathrm{mM} \mathrm{Mg}^{2+}$, although it is clear that dissociation of $\mathrm{Ca}^{2+}$ no longer fits to a single exponential, the precision of the data is insufficient to obtain a unique and reliable fit to the sum of two exponentials (Figure 1). More precise data can be obtained by stopped-flow fluorescence, measuring the change in tryptophan fluorescence that occurs on $\mathrm{Ca}^{2+}$ binding or dissociation. It has been suggested that the tryptophan fluorescence change corresponds to the E2 $\rightarrow \mathrm{E} 1$ (Moutin and Dupont, 1991; Guillain et al., 1981) or E1Ca $\rightarrow$ El'Ca (Fernandez-Belda et al., 1984; Froud and Lee, 1986) steps in Scheme 1, or directly reflects the 


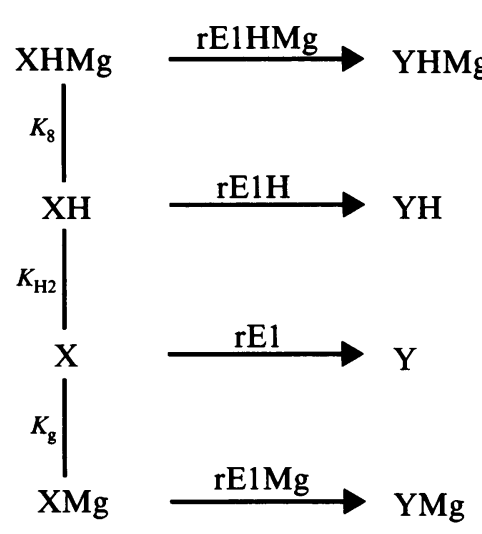

Scheme 3

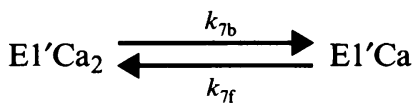

Scheme 4

occupancy of the $\mathrm{Ca}^{2+}$ sites on the ATPase (Orlowski and Champeil, 1991). The data shown in Figure 2 argue strongly that it does not reflect the E2 $\rightarrow$ E1 transition. Perfusion of the ${ }^{45} \mathrm{Ca}^{2+}$ bound ATPase with $\mathrm{Pr}^{3+}$ leads to a biphasic release of ${ }^{45} \mathrm{Ca}^{2+}$ with one-half of the $\mathrm{Ca}^{2+}$ dissociating with a rate comparable with that seen on perfusion with EGTA, the other half dissociating over a time course of minutes. The decrease in tryptophan fluorescence observed on mixing the $\mathrm{Ca}^{2+}$-bound ATPase with $\mathrm{Pr}^{3+}$ follows the same time course as the dissociation of ${ }^{45} \mathrm{Ca}^{2+}$. In the preceding paper (Henderson et al., 1994), it was shown that measurements of the fluorescence of NBD-labelled ATPase indicated that the ATPase was in the El form in the presence of $\operatorname{Pr}^{3+}$.

The results presented in Figure 2 suggest that the tryptophanfluorescence change reflects changes in the $\mathrm{Ca}^{2+}$ occupancy of the ATPase. This is also suggested by the close parallels observed between binding of ${ }^{45} \mathrm{Ca}^{2+}$ and tryptophan-fluorescence changes in equilibrium experiments (Dupont, 1982; Fernandez-Belda et al., 1984; Scofano et al., 1985; Orlowski and Champeil, 1991). This could come about if the change in tryptophan fluorescence occurred at the $\mathrm{E} 1 \mathrm{Ca} \rightarrow \mathrm{E} 1^{\prime} \mathrm{Ca}$ transition, with the equilibrium constant for this step being equal to 1 , and the rate of this step being fast, under most conditions, relative to the rates of the other steps involved in $\mathrm{Ca}^{2+}$ binding and dissociation (Henderson et al., 1994). It will be shown here that this same model can account for changes in tryptophan fluorescence observed by stopped flow on $\mathrm{Ca}^{2+}$ binding or dissociation.

\section{$\mathrm{Ca}^{2+}$ dissociation from the ATPase}

The basic features of the model for $\mathrm{Ca}^{2+}$ binding and dissociation have been largely determined by the equilibrium binding studies detailed in the preceding paper (Henderson et al., 1994). At very low final free $\mathrm{Ca}^{2+}$ concentrations, there will be no rebinding of $\mathrm{Ca}^{2+}$, so that the rate of the fluorescence decrease caused by $\mathrm{Ca}^{2+}$

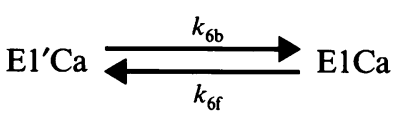

Scheme 5

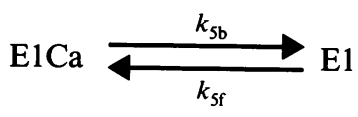

Scheme 6

dissociation will depend on the off rates for the $\mathrm{E} 1^{\prime} \mathrm{Ca}_{2} \rightarrow \mathrm{E} 1^{\prime} \mathrm{Ca}$ and $\mathrm{E} 1 \mathrm{Ca} \rightarrow \mathrm{E} 1$ transitions, and on the forward and back rates for the $\mathrm{El} 1^{\prime} \mathrm{Ca} \rightarrow \mathrm{E} 1 \mathrm{Ca}$ step (at $\mathrm{pH} 6.0$ and 7.2 this step is fast and may be treated by the quasiequilibrium method, but at $\mathrm{pH} 8.5$, as will be shown, this step becomes rate-limiting as the calculated rates of $\mathrm{Ca}^{2+}$ dissociation from $\mathrm{El}^{\prime} \mathrm{Ca}_{2}$ and $\mathrm{E} 1 \mathrm{Ca}$ become very fast). The E1-E2 equilibrium will have no effect, as there is no rebinding of $\mathrm{Ca}^{2+}$ to $\mathrm{E} 1$.

As shown in Figures 1 and 3, the rates of the tryptophanfluorescence changes observed when the $\mathrm{Ca}^{2+}$-bound ATPase is mixed with EGTA increase with increasing $\mathrm{pH}$. The rate of the tryptophan-fluorescence change at $\mathrm{pH} 7.2$ increases on addition of $\mathrm{Mg}^{2+}$ (Figure 1), as previously reported by Moutin and

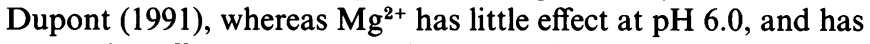
a complex effect at $\mathrm{pH} 8.5$ (Figure 3 ). The observation that $\mathrm{H}^{+}$ and $\mathrm{Mg}^{2+}$ affect the rates of the tryptophan-fluorescence changes indicates that $\mathrm{H}^{+}$and $\mathrm{Mg}^{2+}$ must be able to bind to $\mathrm{El}^{\prime} \mathrm{Ca}_{2}$, at a site referred to in the preceding paper (Henderson et al., 1994) as the 'gating' site. Effects on dissociation of $\mathrm{Ca}^{2+}$ from $\mathrm{E1}^{\prime} \mathrm{Ca}_{2}$ and from $\mathrm{E} 1 \mathrm{Ca}$ and effects on the $\mathrm{El}^{\prime} \mathrm{Ca} \rightarrow \mathrm{E} 1 \mathrm{Ca}$ transition are all described in Scheme 3 where $\mathrm{X}$ and $\mathrm{Y}$ represent $\mathrm{El}^{\prime} \mathrm{Ca}_{2}$ and El'Ca respectively.

If the binding of $\mathrm{H}^{+}$and $\mathrm{Mg}^{2+}$ are fast so that they can be treated by the quasiequilibrium approach (this will be justified later), then the effective rate $k_{7 \mathrm{~b}}$ for dissociation of the first $\mathrm{Ca}^{2+}$ from $\mathrm{El}^{\prime} \mathrm{Ca}_{2}$ (Scheme 4) can readily be calculated as a function of $\mathrm{pH}$ and $\mathrm{Mg}^{2+}$ concentration.

As described in the preceding paper (Henderson et al., 1994), the equilibrium constant for the $\mathrm{E} 1^{\prime} \mathrm{Ca} \rightarrow \mathrm{E} 1 \mathrm{Ca}$ transition has been fixed at 1 . As described below, the rate of this step and its dependence on $\mathrm{pH}$ and $\mathrm{Mg}^{2+}$ concentration is fixed by the data obtained at $\mathrm{pH} 8.5$ and fits Scheme 3 with $\mathrm{X}$ and $\mathrm{Y}$ representing $\mathrm{E} 1^{\prime} \mathrm{Ca}$ and $\mathrm{E} 1 \mathrm{Ca}$ respectively. Again under quasiequilibrium conditions, the effective rate constants $k_{6 \mathrm{~b}}$ and $k_{6 \mathrm{f}}$ (Scheme 5) can be calculated. The rate of the $\mathrm{E} 1 \mathrm{Ca} \rightarrow \mathrm{E} 1$ step (Scheme 6 ) is also assumed to be dependent on occupation of the 'gating' site by $\mathrm{H}^{+}$and $\mathrm{Mg}^{2+}$ as described by Scheme 3 with $\mathrm{X}$ and $\mathrm{Y}$ representing $\mathrm{E} 1 \mathrm{Ca}$ and E1.

Rate constants giving good fits to the data are presented in Table 1. The observed small effect of $\mathrm{Mg}^{2+}$ on the rate of tryptophan-fluorescence change at $\mathrm{pH} 6.0$ (Figure 3) indicates similar rates of $\mathrm{Ca}^{2+}$ dissociation from $\mathrm{El}^{\prime} \mathrm{Ca}_{2} \mathrm{HMg}$ and $\mathrm{El}^{\prime} \mathrm{Ca}_{2} \mathrm{H}$ and from $\mathrm{E} 1 \mathrm{CaHMg}$ and $\mathrm{E} 1 \mathrm{CaH}$. The faster rate observed at higher $\mathrm{pH}$ indicates faster rates of $\mathrm{Ca}^{2+}$ dissociation from unprotonated than from protonated species. The single exponential fit observed for the $\mathrm{pH} 6.0$ data defines the rate of dissociation of $\mathrm{Ca}^{2+}$ from $\mathrm{El}^{\prime} \mathrm{Ca}_{2} \mathrm{H}$ as being twice that from $\mathrm{E} 1 \mathrm{Ca}$, as described in the Appendix. The observed biexponential change observed at $\mathrm{pH} 8.5$ in the absence of $\mathrm{Mg}^{2+}$ and the 
decrease in rate observed at $\mathrm{pH} 8.5$ at high $\mathrm{Mg}^{2+}$ can be simulated assuming that the rate of the $\mathrm{E} 1^{\prime} \mathrm{Ca} \rightarrow \mathrm{E} 1 \mathrm{Ca}$ step becomes slower than the rates of the $\mathrm{El}^{\prime} \mathrm{Ca}_{2} \rightarrow \mathrm{El}{ }^{\prime} \mathrm{Ca}$ and $\mathrm{E} 1 \mathrm{Ca} \rightarrow \mathrm{El}$ steps at this $\mathrm{pH}$ (Figures 3 and 5).

Decreases in tryptophan-fluorescence intensity on $\mathrm{Ca}^{2+}$ dissociation at higher $\mathrm{pCa}$ values show an initial small rapid phase followed by a larger and slower change (Figure 6). As the larger slow phase fits to a single exponential, and as the presence of the small initial fast phase has little effect on the goodness of fit, it is convenient to describe these curves by the amplitude and rate parameters obtained from a single exponential fit. Figure 7 shows the variation of amplitude and rate with $\mathrm{pCa}$ at $\mathrm{pH} 6.0$ in the absence and presence of $20 \mathrm{mM} \mathrm{Mg}{ }^{2+}$. The variation of amplitude with $\mathrm{pCa}$ is identical with the variation of tryptophanfluorescence intensity with $\mathrm{pCa}$ observed in equilibrium binding experiments (Henderson et al., 1994). Importantly, however, as the $\mathrm{Ca}^{2+}$ concentration increases, the rate of the tryptophanfluorescence change decreases, with an apparent high affinity for $\mathrm{Ca}^{2+}$. As shown in the Appendix the variation of rates and amplitudes with $\mathrm{pCa}$ depends on the relative affinities of $\mathrm{E} 1$ and $\mathrm{El}^{\prime} \mathrm{Ca}$ for $\mathrm{Ca}^{2+}$; the effective affinity of $\mathrm{E} 1$ for $\mathrm{Ca}^{2+}$ must be much lower than that of $\mathrm{El}^{\prime} \mathrm{Ca}$ to obtain the observed dependence on $\mathrm{pCa}$ (Appendix). The apparent affinity of $\mathrm{E} 1$ for $\mathrm{Ca}^{2+}$ is defined by the intrinsic affinity of the site for $\mathrm{Ca}^{2+}$, by binding of $\mathrm{H}^{+}$and $\mathrm{Mg}^{2+}$ at the $\mathrm{Ca}^{2+}$-binding site and by the E2-E1 equilibrium. All of these constants except that defining the intrinsic affinity for $\mathrm{Ca}^{2+}$ have been defined by experiments with NBD-labelled ATPase (Henderson et al., 1994). The value of the intrinsic affinity for the first $\mathrm{Ca}^{2+}$ site was therefore chosen to fit the data in Figures 6 and 7, with the value for the intrinsic affinity of $\mathrm{Ca}^{2+}$ for the second site then being chosen to fit the equilibrium $\mathrm{Ca}^{2+}$ binding data (Henderson et al., 1994). The binding constants describing these processes are given in the preceding paper (Henderson et al., 1994) (see also Table 1).

At $\mathrm{pH} 7.2$ differences between the $\mathrm{Ca}^{2+}$-dependencies of rate and amplitude are considerably smaller than observed at $\mathrm{pH} 6.0$ (Figure 7). For the experiment shown in Figure 7, the $\mathrm{Ca}^{2+}$ dependence of the change in amplitude of the fluorescence change was different from that observed in equilibrium binding experiments at pH 7.2 (Henderson et al., 1994). However, the affinity of the ATPase for $\mathrm{Ca}^{2+}$ has been observed to vary between preparations (Lee et al., 1983; Orlowski and Champeil, 1991), and the data shown in Figure 7 can be reproduced with a binding constant for the second $\mathrm{Ca}^{2+}$ a factor of two smaller than that given in Table 1 .

It is assumed in all the simulations that binding of $\mathrm{H}^{+}$to all sites and binding of $\mathrm{Mg}^{2+}$ to the second $\mathrm{Ca}^{2+}$-binding site are fast and can be treated by the quasiequilibrium approach. This assumption is justified by $\mathrm{pH}$-jump and $\mathrm{Mg}^{2+}$-jump experiments. As shown in Figure 9, the rate of change of fluorescence observed in $\mathrm{Ca}^{2+}$-dissociation experiments in which the $\mathrm{pH}$ was jumped from 8.5 to 6.0 was the same as that observed when the ATPase was incubated at pH 6.0 (see Figure 7) and similarly the rate observed with a pH jump from 6.0 to 8.5 was the same as that observed after preincubation at pH 8.5 (Figure $3 b$ ). Similarly, experiments at $\mathrm{pH} 7.2$ in which the ATPase was either preincubated in $10 \mathrm{mM} \mathrm{Mg}^{2+}$ or incubated in the absence of $\mathrm{Mg}^{2+}$ then mixed in a 1:1 ratio with $20 \mathrm{mM} \mathrm{Mg}^{2+}$ gave identical kinetics for the change in tryptophan fluorescence on $\mathrm{Ca}^{2+}$ dissociation (results not shown).

\section{$\mathrm{Ca}^{2+}$ binding to the ATPase}

The rate of $\mathrm{Ca}^{2+}$ binding to the ATPase is affected by the rate of the E2 $\rightarrow \mathrm{E} 1$ transition. Analysis of the rate of the NBD fluorescence change for NBD-labelled ATPase on jumping the $\mathrm{pH}$ from 6.0 to 8.5 and of the rate of reversal of the effects of inhibitors of the ATPase due to $\mathrm{Ca}^{2+}$ binding (Figures 10 and 11) define this rate (Table 1), as described in the Results section. The $\mathrm{Ca}^{2+}$-binding rates are defined by the dissociation rates and the equilibrium constants (Table 1). The only undefined rate parameters are then those describing $\mathrm{Mg}^{2+}$ binding to the first $\mathrm{Ca}^{2+}$ binding site. As shown in Figure 12, $\mathrm{Mg}^{2+}$ has little effect on the rate of the tryptophan-fluorescence change after $\mathrm{Ca}^{2+}$ binding at $\mathrm{pH} 6.0$ but markedly increases the rate observed at $\mathrm{pH} 7.2$. At pH 7.2 in the presence of $\mathrm{Mg}^{2+}$ the fluorescence curves fit to sums of two exponentials, with the rate varying relatively little with $\mathrm{Mg}^{2+}$ concentration but with a marked increase in the relative amplitude of the fast component with increasing $\mathrm{Mg}^{2+}$ (Table 2). In terms of Scheme 1, the effect of $\mathrm{Mg}^{2+}$ follows from a $\mathrm{Mg}^{2+}$ induced shift in the $\mathrm{E} 2 \rightarrow \mathrm{E} 1$ equilibrium towards $\mathrm{E} 1$. With the binding constants for $\mathrm{Mg}^{2+}$ estimated in Henderson et al. (1994) for NBD-labelled ATPase, it was only found possible to simulate the effect of $\mathrm{Mg}^{2+}$ assuming a low rate of dissociation of $\mathrm{Mg}^{2+}$ from the first $\mathrm{Ca}^{2+}$-binding site in the E2 conformation [Table 1; Scheme 5 in (Henderson et al., 1994)]. However, it is possible that NBD labelling reduces the affinity of the ATPase for $\mathbf{M g}^{2+}$ (Henderson et al., 1994), and the data in Table 2 can also be simulated with fast dissociation of $\mathrm{Mg}^{2+}$ if the binding constant for $\mathrm{Mg}^{2+}$ for the unlabelled ATPase is three times that of the labelled ATPase (Table 1).

As shown, with the parameters in Table 1, it is possible to simulate the rate of tryptophan change on $\mathrm{Ca}^{2+}$ binding at $\mathrm{pH}$ 6.0, 7.2 and 8.5 (Figure 12), the effect of $\mathrm{Mg}^{2+}$ on the rates and amplitudes of the two exponentials required to fit the data at $\mathrm{pH} 7.2$ (Table 2) and the inhibitory effect of $\mathrm{Mg}^{2+}$ at $\mathrm{pH} 8.5$ (Figure 12, Table 3) which, in the proposed model, occurs because of $\mathrm{Mg}^{2+}$ inhibition of the $\mathrm{E} 1 \mathrm{Ca} \rightarrow \mathrm{E} 1^{\prime} \mathrm{Ca}$ step.

Effects of $\mathrm{pH}$ and $\mathrm{Mg}^{2+}$ jumps are more complex on $\mathrm{Ca}^{2+}$ binding than on $\mathrm{Ca}^{2+}$ dissociation. Thus Figure 13(a) shows that when the $\mathrm{pH}$ is jumped from 8.5 to 6.0 , an initial rapid phase is observed before the slower change typical of $\mathrm{pH}$ 6.0. This effect does not indicate slow binding of $\mathrm{H}^{+}$to a site on the ATPase, but rather follows from the high proportion of the ATPase in the E1 state at high $\mathrm{pH}$; the magnitude of the initial fast phase depends on the relative rates of $\mathrm{Ca}^{2+}$ binding and of the $\mathrm{E} 1 \rightarrow \mathrm{E} 2$ transition, and is reproduced well in the simulations. In $\mathrm{pH}$ jumps from 6.0 to 8.5 , a lag phase is observed. Again, this does not represent slow dissociation of $\mathrm{H}^{+}$from some site on the ATPase but rather reflects the rate of the E2 $\rightarrow \mathrm{E} 1$ transition at $\mathrm{pH} 8.5$; the lag phase is also reproduced well in the simulations.

At $\mathrm{pH}$ 6.0, jumps in $\mathrm{Mg}^{2+}$ concentration have no effect on the time course of the tryptophan-fluorescence change on binding $\mathrm{Ca}^{2+}$ (results not shown), consistent with the lack of effect of $\mathrm{Mg}^{2+}$ on the rate of change of tryptophan fluorescence at $\mathrm{pH} 6.0$ (Figure 12). However, at pH 7.2, the rate of change of tryptophan fluorescence on binding $\mathrm{Ca}^{2+}$ after a jump in $\mathrm{Mg}^{2+}$ concentration from 0 to $20 \mathrm{mM}$ is slower than that observed when the ATPase is preincubated with $20 \mathrm{mM} \mathrm{Mg}{ }^{2+}$ (Figure 14a). Simulations (Figure 14a) show that this effect arises because of the increased proportion of E1 forms of the ATPase present at $\mathrm{pH} 7.2$ in the presence of $\mathrm{Mg}^{2+}$ (Henderson et al., 1994). At pH 8.5, the rate of change of tryptophan fluorescence is the same for a jump in $\mathrm{Mg}^{2+}$ concentration from 0 to $20 \mathrm{mM}$ or after preincubation with $20 \mathrm{mM} \mathrm{Mg}^{2+}$ (Figure 14b). This is also reproduced in the simulations (Figure 14b) and follows partly from the suggestion that the ATPase is largely in the E1 form at $\mathrm{pH} 8.5$, even in the absence of $\mathrm{Mg}^{2+}$ (Henderson et al., 1994) and partly from the suggestion that, at $\mathrm{pH} 8.5$, the rate of the tryptophan-fluorescence 
change is largely controlled by the rate of the $\mathrm{ElCa} \rightarrow \mathrm{El}^{\prime} \mathrm{Ca}$ step.

We thank Professor H. D. White for his very generous provision of the source code for the simulation program M30 and Dr. M. Holub for the generous gift of a sample of trilobolide. We thank the SERC, Wellcome Trust and Wessex Medical Trust for financial support and the SERC for a studentship (to I.M.J.H.).

\section{REFERENCES}

Cha, S. (1968) J. Biol. Chem. 243, 820-825

Champeil, P., Gingold, M. P., Guillain, F. and Inesi, G. (1983) J. Biol. Chem. 258, 4453-4458

Chance, E. M., Curtis, A. R., Jones, I. P. and Kirby, C. R. (1977) FACSIMILE: A computer Program for Flow and Chemistry Simulations, HMSO, London

Dupont, Y. (1982) Biochim. Biophys. Acta 688, 75-87

Dupont, Y. (1984) Anal. Biochem. 142, 504-510

Dupont, Y. and Leigh, J. B. (1978) Nature (London) 273, 396-398

Fernandez-Belda, F., Kerzmack, M. and Inesi, G. (1984) J. Biol. Chem. 259, 96879698

Froud, R. J. and Lee, A. G. (1986) Biochem. J. 237, 197-206

Godt, R. E. (1974) J. Gen. Physiol. 63, 722-739

\section{APPENDIX}

\section{Dissociation of $\mathrm{Ca}^{2+}$ from the $\left(\mathrm{Ca}^{2+}-\mathrm{Mg}^{2+}\right)-$ ATPase}

Dissociation of $\mathrm{Ca}^{2+}$ from two independent identical sites on the ATPase can be described as two independent reactions of the form:

$$
\mathrm{E} 1 \mathrm{Ca} \underset{k_{21} \mathrm{Ca}}{\stackrel{k_{12}}{\rightleftharpoons}} \mathrm{E} 1
$$

The concentration of the $\mathrm{Ca}^{2+}$-bound ATPase at any time $t$, $[\mathrm{E} 1 \mathrm{Ca}]_{t}$ is then given as a function of the concentration at time $0,[\mathrm{E} 1 \mathrm{Ca}]_{0}$ [see Benson (1960)] as:

$$
\frac{[\mathrm{E} 1 \mathrm{Ca}]_{t}}{[\mathrm{E} 1 \mathrm{Ca}]_{0}}=1-\alpha\left(1-\mathrm{e}^{-\lambda t}\right)
$$

where

$$
\alpha=\frac{1}{1+K C a}
$$

and

$$
\lambda=k_{12}(1+K \mathrm{Ca})
$$

and the equilibrium constant for $\mathrm{Ca}^{2+}$. binding $K=k_{21} / k_{12}$.

This equation predicts that the amplitude of the tryptophan fluorescence change will decrease with increasing $\mathrm{Ca}^{2+}$, but that the rate of the change will increase with increasing $\mathrm{Ca}^{2+}$. Both will have the same dependence on the concentration of $\mathrm{Ca}^{2+}$, given by $K$. This is not what is observed experimentally, so that $\mathrm{Ca}^{2+}$ dissociation cannot occur from two independent sites.

Under conditions where the $\mathrm{El}^{\prime} \mathrm{Ca} \rightarrow \mathrm{E} 1 \mathrm{Ca}$ step is fast and at low $\mathrm{Ca}^{2+}$ concentrations so that no back reactions occur, Scheme 1 for $\mathrm{Ca}^{2+}$ dissociation simplifies to:

$$
\mathrm{E} 1 \mathrm{Ca}_{2} \underset{k_{21} \mathrm{Ca}}{\stackrel{k_{12}}{\rightleftharpoons}} \mathrm{E} 1 \mathrm{Ca} \underset{k_{32} \mathrm{Ca}}{\stackrel{k_{23}}{\rightleftharpoons}} \mathrm{E} 1
$$

This is a special case of that considered by Lowry and John (1910):

$$
A_{1} \underset{k_{21}}{\stackrel{k_{12}}{\rightleftharpoons}} A_{2} \underset{k_{32}}{\stackrel{k_{23}}{\rightleftharpoons}} A_{3}
$$

Guillain, F., Gingold, M. P., Buschlen, S. and Champeil, P. (1980) J. Biol. Chem. 255 , 2072-2076

Guillain, F., Champeil, P., Lacapere, J. J. and Gingold, M. P. (1981) J. Biol. Chem. 256, 6140-6147

Henderson, I. M. J., Khan, Y. M., East, J. M. and Lee, A. G. (1994) Biochem. J. 297 $615-624$

Hille, B. (1984) Ionic Channels of Excitable Membranes, Sinauer Associates Inc., Sunderland, MA

Inesi, G. (1987) J. Biol. Chem. 262, 16338-16342

Lee, A. G., East, J. M., Jones, O. T., McWhirter, J., Rooney, E. K. and Simmonds, A. C. (1983) Biochim. Biophys. Acta 732, 441-454

Moutin, M. J. and Dupont, Y. (1991) J. Biol. Chem. 266, 5580-5586

Orlowski, S. and Champeil, P. (1991) Biochemistry 30, 352-361

Petithory, J. R. and Jencks, W. P. (1988) Biochemistry 27, 5553-5564

Scofano, H., Barrabin, H., Inesi, G. and Cohen, J. A. (1985) Biochim. Biophys. Acta 819, 93-104

Squier, T. C., Bigelow, D. J., Fernandez-Belda, F. J., deMeis, L. and Inesi, G. (1990) J. Biol. Chem. 265, 13713-13720

Starling, A. P., East, J. M. and Lee, A. G. (1993) Biochemistry 32, 1593-1600

Wakabayashi, S., Ogurusu, T. and Shigekawa, M. (1990) Biochemistry 29, 10613-10620

Wictome, M., Henderson, I., Lee, A. G. and East, J. M. (1992a) Biochem. J. 283, 525-529

Wictome, M., Michelangeli, F., Lee, A. G. and East, J. M. (1992b) FEBS Lett. 304, $109-113$

Zhang, X. Z., Strand, A. and White, H. D. (1989) Anal. Biochem. 176, 427-431

Under the conditions that at time $t=0, A_{1}^{t}=A_{1}^{0}$ and $A_{2}^{t}=A_{3}^{t}=$ 0 , the concentrations $A_{1}^{t}, A_{2}^{t}$ and $A_{3}^{t}$ of the three species at time $t$ are given by:

$$
\begin{gathered}
A_{1}^{t}=A_{1}^{0}\left\{\frac{k_{21} k_{32}}{\lambda_{2} \lambda_{3}}+\left[\frac{k_{12}\left(\lambda_{2}-k_{23}-k_{32}\right)}{\lambda_{2}\left(\lambda_{2}-\lambda_{3}\right)}\right] \mathrm{e}^{-\lambda_{2} t}\right. \\
\left.+\left[\frac{k_{12}\left(k_{23}+k_{32}-\lambda_{3}\right)}{\lambda_{3}\left(\lambda_{2}-\lambda_{3}\right)}\right] e^{-\lambda_{3} t}\right\} \\
A_{2}^{t}=A_{1}^{0}\left\{\frac{k_{12} k_{32}}{\lambda_{2} \lambda_{3}}+\left[\frac{k_{12}\left(k_{32}-\lambda_{2}\right)}{\lambda_{2}\left(\lambda_{2}-\lambda_{3}\right)}\right] e^{-\lambda_{2} t}\right. \\
\left.+\left[\frac{k_{12}\left(\lambda_{3}-k_{32}\right)}{\lambda_{3}\left(\lambda_{2}-\lambda_{3}\right)}\right] \mathrm{e}^{-\lambda_{3} t}\right\} \\
A_{3}^{t}=A_{1}^{0}\left\{\frac{k_{12} k_{23}}{\lambda_{2} \lambda_{3}}+\left[\frac{k_{12} k_{23}}{\lambda_{2}\left(\lambda_{2}-\lambda_{3}\right)}\right] \mathrm{e}^{-\lambda_{2} t}\right. \\
\left.-\left[\frac{k_{12} k_{23}}{\lambda_{3}\left(\lambda_{2}-\lambda_{3}\right)}\right] \mathrm{e}^{-\lambda_{3} t}\right\}
\end{gathered}
$$

where

$$
\begin{aligned}
& \lambda_{2}=\frac{1}{2}(p+q) \\
& \lambda_{3}=\frac{1}{2}(p-q)
\end{aligned}
$$

and

$$
\begin{aligned}
& p=k_{12}+k_{21}+k_{23}+k_{32} \\
& q=\left\{p^{2}-4\left(k_{12} k_{23}+k_{21} k_{32}+k_{12} k_{32}\right)\right\}^{\frac{1}{2}}
\end{aligned}
$$

Thus the behaviour of the system is described by just two rate constants $\lambda_{2}$ and $\lambda_{3}$.

The fractional occupancy of the $\mathrm{Ca}^{2+}$ sites, $F$ is given by:

$$
F=A_{1}{ }^{t}+0.5 A_{2}{ }^{t}
$$




\section{Table A1 Rate constants describing $\mathrm{Ca}^{2+}$ dissoclation from the ATPase}

The calculated rate constants $\lambda_{2}$ and $\lambda_{3}$ at various final $\mathrm{pCa}$ values derived from the equations describing two sequential reactions, assuming that $K_{1}=10^{6} \mathrm{M}^{-1}$ and $k_{12}=k_{23}=10.0 \mathrm{~s}^{-1}$, together with the rate $(k)$ and amplitude obtained when the calculated lines are fitted to a single exponential.

\begin{tabular}{cccccc}
\hline & $\mathrm{pCa}$ & $\lambda_{2}\left(\mathrm{~s}^{-1}\right)$ & $\lambda_{3}\left(\mathrm{~s}^{-1}\right)$ & $k\left(\mathrm{~s}^{-1}\right)$ & Amplitude \\
\hline \multirow{2}{*}{$K_{2}=10^{6}$} & 7.0 & 142 & 7.8 & 6.7 & 0.98 \\
& 6.5 & 18.8 & 7.6 & 7.0 & 0.83 \\
& 6.0 & 7.0 & 10.0 & 10.0 & 0.50 \\
& 5.5 & 59.4 & 23.8 & 25.5 & 0.18 \\
$K_{2}=10^{4}$ & 5.0 & 141.6 & 78.4 & 86.7 & 0.05 \\
& 7.0 & 13.7 & 7.3 & 6.3 & 1.03 \\
& 6.5 & 17.4 & 5.76 & 5.5 & 1.01 \\
& 6.0 & 26.2 & 3.89 & 4.0 & 0.96 \\
& 5.5 & 49.7 & 2.28 & 2.35 & 0.85 \\
& 5.0 & 119 & 1.76 & 1.81 & 0.47 \\
\hline
\end{tabular}

Equilibrium constants for $\mathrm{Ca}^{2+}$ binding are defined by:

$$
K_{1}=\frac{k_{32}}{k_{23}} \quad K_{2}=\frac{k_{21}}{k_{12}}
$$

Under conditions where back reactions can be ignored (low $\mathrm{Ca}^{2+}$ concentrations), the equations simplify to:

$$
F=\frac{\left(2 k_{23}-k_{12}\right) \mathrm{e}^{-k_{12} t}-k_{12} \mathrm{e}^{-k_{23} t}}{k_{23}-k_{12}}
$$

and if $k_{23}=k_{12} / 2$, then the equation simplifies further to a single exponential with rate $k_{23}$.

When the back reactions become significant, simplification is not possible. Typical simulations under these conditions are shown in Figure A1. $K_{2}, k_{12}$ and $k_{23}$ were set at $10^{6}, 10 \mathrm{~s}^{-1}$ and $10 \mathrm{~s}^{-1}$ respectively for all simulations. In the first set of calculations, $K_{1}$ was fixed at $10^{6}$, equal to $K_{2}$ and the calcium occupancy $(F)$ against time calculated according to the above equations for various final $\mathrm{Ca}^{2+}$ concentrations. Values of the calculated rates $\lambda_{2}$ and $\lambda_{3}$ are given in Table Al. At lower pCa values, an initial fast phase is clearly present in the simulations (as in the experimental data, see Figure 6). Nevertheless, the simulated curves fit reasonably well to single exponentials. The rate derived by the curve fitting is close to the value of the slow component $\lambda_{3}$ (Table A1). The rate of $\mathrm{Ca}^{2+}$ dissociation increases with increasing $\mathrm{Ca}^{2+}$ concentration, whereas the experimental data show a decrease in rate with increasing $\mathrm{Ca}^{2+}$ concentration.

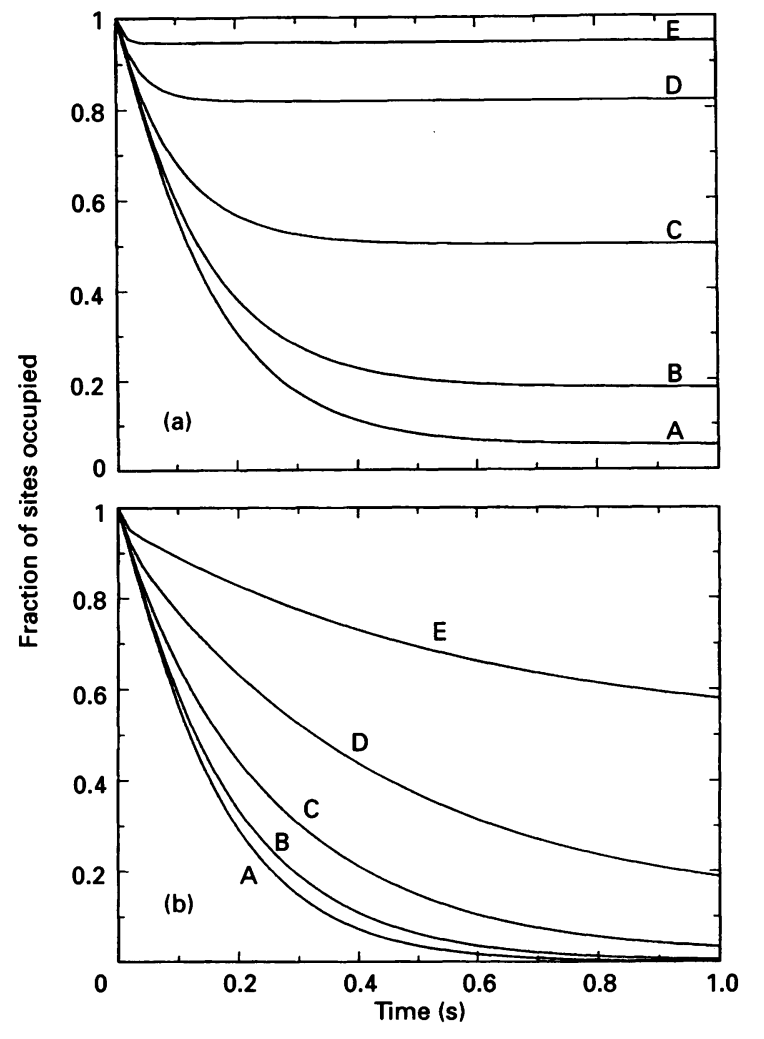

Figure A1 Simulation of the effect of $\mathrm{Ca}^{2+}$ concentration on $\mathrm{Ca}^{2+}$ dissociation from the ATPase

The figure shows simulations of $\mathrm{Ca}^{2+}$ dissociation according to the above equations, with $K_{1}=10^{6}, k_{12}=k_{23}=10 \mathrm{~s}^{-1}$ and $K_{2}=10^{6}$ (a) or $10^{4}$ (b) and pCa values of: A, 7.0; B, $6.5 ; C, 6.0 ; D, 5.5 ; E, 5.0$.

The simulations were reported with $K_{1}=10^{4}$ (Figure A1) with the calculated rates $\lambda_{2}$ and $\lambda_{3}$ at each pCa value given in Table Al. Again the simulated curves fitted well to a single exponential with a rate close to the value of $\lambda_{3}$. In this case, however, the rate of decrease in $\mathrm{Ca}^{2+}$ occupancy decreases with increasing $\mathrm{Ca}^{2+}$ concentration, as is the case with the experimental data.

Simulations therefore show that $K_{1}$ must be less than $K_{2}$ for the rate of dissociation to decrease with increasing $\mathrm{Ca}^{2+}$ concentration.

\section{REFERENCES}

Benson, S. W. (1960) The Foundation of Chemical Kinetics, McGraw-Hill, New York Lowry, T. M. and John, W. T. (1910) J. Chem. Soc. 97, 2634-2645 